\title{
障害者支援施設の支援と建築構成の実態 \\ -対象障害と個室・エニット化、昼夜分離等に着目してー \\ ACTUAL CONDITIONS OF SUPPORT AND ARCHITECTURAL CONFIGURATION OF FACILITIES FOR PERSONS WITH DISABILITIES
}

Focusing on target disabilities and private rooms, unit care, day/night separation, etc.

荒川実緒子*1, 松田雄二*2

\section{Mioko ARAKA WA and Yuji MATSUDA}

\begin{abstract}
In this study, a questionnaire survey of support facilities for persons with disabilities throughout Japan, and a floor plan analysis on some of those facilities were conducted. The results are as follows: 1) Support policies and support systems tend to differ depending on the characteristics of the residents, and these may also be related to the composition of the facility. 2) Various practices are being implemented in terms of private rooms, unit care, and day/night separation, and the overview of these practices and points to be considered when implementing them were clarified.
\end{abstract}

Keywords: Support Facilities for Persons with Disabilities, Intellectual Disability, Physical Disability, Unit Care, Nationwide Survey 障害者支援施設，知的障害，身体障害，ユニットケア，全国調査

\section{1. 研究の背景と目的}

\section{1 - 1. 研究の背景}

2006 年の障害者自立支援法（2014 年に障害者総合支援法に改正） 施行により、障害種別ごとに定められていた制度が一元化された。 また、障害福祉サービスは夜間の支援を行う居住系サービスと日中 活動系サービスに分割され、それらを組み合わせて提供されること となり、療護・更生・授産施設等の入所施設は障害者支援施設注1)

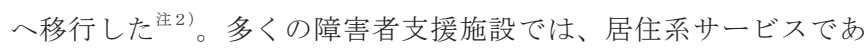
る「施設入所支援」と共に日中活動系サービスである「生活介護」 等のサービスが提供され、日中の活動としては、多くの施設では「生 活介護」のサービスとして入浴や食事のほか、創作・生産活動など 様々な活動が行われている注3)。居住の場については、「施設から地 域」への流れの中でグループホーム等への転換が図られているが、 最重度の障害のある人々の受け典として障害者支援施設が位置付け られ、全国の約 2500 施設で約 13 万人が生活している注4)

三菱U F J リサーチ\&コンサルティングによる調查（2019） 11 によると、障害者支援施設は、地域支援体制の中で昼間実施开ービ ス・相談機能・医療的ケア等の入所以外の機能により、地域支援体 制の中心として地域移行を促進する役割を求められている。一方 で、現状として地域支援体制が不足しており、地域での生活が難し い人の多くが施設で生活している状況を踏まえ、生活単位の小規模 化や個室化といった居住環境の整備・日中の活動の場と居住の場の 分離（以下、「昼夜分離」とする）等、障害者支援施設における生
活の質の向上への取組みが期待されている。しかし、現状の施設に おいてこれらの取組みがどの程度実施されているかは明らかでな い。また、現状で定められている施設整備基準は居室面積 $\left(9.9 \mathrm{~m}^{2}\right.$ 以上)、居室定員（4名以下）等注5) に留まり、将来的に望ましい整 備水準を示しているとは言えない状況である。

\section{$1-2$. 既往の研究}

知的障害者福祉協会 $(2018)^{2}{ }^{2)}$ による会員事業所を対象とした悉 皆調查では、建替えの必要性が高いこと、全体の部屋数の $57.1 \%$ が個室であること、施設入所支援利用者の日中の活動の場は「同一 法人敷地内」が $90 \%$ を超える状況が続いていること等が示されてい る。また、山田他 $(2011)^{3)}$ は旧法上の身体障害者療護施設・知 的障害者更生施設・重症心身障害児者施設を対象として、施設の現 況報告を行い、対象障害による環境へのニーズを考察した。しかし、 制度移行後の障害者支援施設における、利用者の生活環境や建築構 成に関する全国的な概況を示すデータの蓄積は十分でない。

次に、入所系施設の居住環境・日中活動環境に着目した研究を整 理する。居住環境に関しては、主にユニットケアについての調査が 行われている。ユニット型施設の整備基準が定められている高齢者 施設分野では、平面計画に関する研究の蓄積があり、中でも石井 ${ }^{(2011)^{4}}{ }^{4)}$ は調查時点での全国ほぼ全ての特養・老健を対象として、 ユニット内および居室の計画を中心に、施設種別・立地・自治体間 での特徴や開設年からみる経年的な傾向を明らかにした。また、石 垣等 $(2012)^{5)}$ は児童養護施設における生活単位小規模化につい
"1 元 東京大学大学院工学系研究科建築学専攻 修士課程

2 東京大学大学院工学系研究科建築学専攻 准教授・博士 (工学)
Former Grad. Student, Dept. of Arch., Grad. School of Eng., The Univ. of Tokyo Assoc. Prof., Dept. of Arch., Grad. School of Eng., The Univ. of Tokyo, Dr.Eng. 
て施設運営と建築構成の実態を示した。一方、障害者施設分野では、 三菱U F J リサーチ\&コンサルティング (2010) ${ }^{6)}$ は旧法体系施 設と障害者支援施設を対象とした調查より、ユニットケアの状況に ついて、全体の $13.1 \%$ で実施されていることや、その効果と課題 を示している。障害者施設の計画に関する研究としては、松村他 ${ }^{(2005)}{ }^{7)}$ は旧法上の身体障害者療護施設を対象とした事例調查か ら生活単位の小規模化の効果を職員の評価より確認し、また宮崎他 ${ }^{(2012)}{ }^{8)}$ は知的障害者支援施設を対象とした事例調查から個室二 ニット化の効果を検証している。松岡他 (2014) ${ }^{9)}$ は身体障害者 支援施設におけるユニットの区分け方法のパターン化を行った。そ の他居住空間については、亀屋（2009） ${ }^{10)}$ は旧法上の身体障害者 療護施設におけるALS 罹病者の居室に着目し、物理的な設備以外の 生活時間を充足させるような施設環境整備の補完の必要性を論じ た。また日中活動環境に関して、鈴木他（2016） ${ }^{11)}$ は 1 事例の観 察調查を通して、利用者の個別エリア空間の類型化を行い、それぞ れの利点と課題をまとめている。

これらは、施設の居住環境・日中活動環境それぞれに着目した研 究であるが、施設入所支援に加えて生活介護等の日中サービスも提 供し、24 時間の生活を支援する場合が多い障害者支援施設につい ては、居住と日中活動環境の繋がりを含めた施設の全体構成に関す る知見も重要である。施設の全体計画に関しては、佐藤他（1984） 12,13) が旧法上の重度身体障害者収容授産施設を対象として、主に 居住・作業・管理部門の構成方法や面積構成に関する分析を行って おり、本研究でも分析手法を参考とした。

\section{$1-3$. 研究の目的}

既往の研究からは、障害者支援施設の計画を考える上で重要であ ると思われる、夜間と日中の生活の実態について、明らかにはなっ ていない。具体的には、個室・ユニットケアの状況や、日中活動が 時間を定めた「プログラム」として提供されているのか、プログラ ムへの入居者の参加方法（必ず参加するのか、それとも参加は任意 か)、また支援の考え方として昼夜分離の考え方を採用しているの か、などである。本研究では、全国の障害者支援施設を対象に、こ れらの点を明らかにするとともに、具体的な面積構成を明らかにす ることで、今後の施設整備における基礎的な条件の整理を行う事を 目的とする。

\section{2. 調査方法}

\section{2-1. アンケート調査}

本研究では、事前に各都道府県のホームページやWAMNET ${ }^{\text {i主 6) }}$ を用いて把握した全国の障害者支援施設 2477 施設を対象として、 郵送による悉皆アンケート調査を実施した。主に利用者の状況・建 物の状況・運営状況等の施設全体に関して、また日中活動の場と居 住の場の環境に関して、施設の現況と職員の意向といった観点から 質問を行い、1151施設（46.5\%）から回答を得た。調查概要と質 問項目をTable 1 に示す。また、同時に施設平面図の提供を依頼し、 376 施設から提供いただいた。

\section{2-2. 平面構成調査}

アンケート調査に基づき、施設より提供いただいた 376 平面図の うち、室名・寸法や面積の記載がある 230 施設について、施設の全 体構成と面積構成に関する調查を行った (Table 2)。主な調查項目
は、施設の全体構成については昼夜分離の構成方法注7)等、また面 積構成については各部門面積・居室面積・活動室面積である。本調 查では、面積構成について、居住部門・活動部門・共用部門・管理 部門・サービス部門・廊下部門・医療部門・地域交流部門・収納部

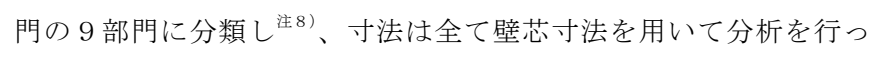
た (Table 3 )。

Table 1 Overview of questionnaire / アンケート調査の概要

$\begin{array}{cc}\text { Subjests } & 2477 \text { support facilities for persons with disabilities in Japan } \\ \text { / 調查対象 } & \text { / 全国の障害者支援施設 } 2477 \text { 施設 }\end{array}$

/ 調査対象 / 全国の障害者支援施設 2477 施設

Methods Questionnaire by mail (From October 1 to November 30, 2019)

/調査方法 / 郵送によるアンケート調査（2019 年 10 月 1 日〜 11 月 30 日）

Returned/ 回収数 $1151(46.5 \%)$

1.About overview of facility

/ 施設概要（建物概要、入居者概要、運営概要等）

2.About activity space

Question Items / 日中活動の場について (活動方針、昼夜分離、敷地外事業所の利用状況等)

/ 質問項目 3.About living space

/ 居住の場について（居室定員、支援単位、ユニットケア概要等）

4.About staff intentions for the care

/ 職員の意向について (定員規模意向、支援単位規模意向、建物改善点等)

Table 2 Overview of floor plan survey / 平面構成調査の概要

Subjests 230 support facilities for persons with disabilities in Japan

/ 調査対象 / 全国の障害者支援施設 230 施設

Methods Read the spatial configuration from the floor plan and measure the area by

/ 調査方法 department for some facilities. / 平面

Question items 1.About architectural configuration/ 空間構成（日中活動の場と居住の場の構成）

/ 調査項目 2.About area composition/面積構成（部門別面積割合、居室面積、活動室面積等）

\begin{tabular}{|c|c|}
\hline Living department / 居住部門 & living room / 居室 \\
\hline $\begin{array}{l}\text { Acrivity department } \\
\text { /活動部門 }\end{array}$ & $\begin{array}{l}\text { activity room,snoezelen,exercise space,locker room,etc. } \\
\text { /活動室、スヌーズレン、運動スペース、更衣室等 }\end{array}$ \\
\hline $\begin{array}{l}\text { Common department } \\
\text { / 共用部門 }\end{array}$ & $\begin{array}{l}\text { dining hall,living room,dayroom,toilet,bath room,etc. } \\
\text { / 食堂、リビング、デイルーム、トイレ、浴室等 }\end{array}$ \\
\hline $\begin{array}{l}\text { Managing department } \\
\text { /管理部門 }\end{array}$ & $\begin{array}{l}\text { office,staff room,conference room,locker room,staff toilet,etc } \\
\text { / 事務室、支援員室、会議室、職員更衣室、職員トイレ等 }\end{array}$ \\
\hline $\begin{array}{l}\text { Service department } \\
\text { /サービス部門 }\end{array}$ & $\begin{array}{l}\text { kitchen,laundry room,machine room,etc. } \\
\text { / 厨房、洗濯室、機械室等 }\end{array}$ \\
\hline $\begin{array}{l}\text { Corridor department } \\
\quad \text { / 廊下部門 }\end{array}$ & $\begin{array}{l}\text { entrance,hall,corridor,stairs,elevator } \\
\text { /玄関、ホール、廊下、階段、EV }\end{array}$ \\
\hline $\begin{array}{l}\text { Medical department } \\
\text { / 医療部門 }\end{array}$ & $\begin{array}{l}\text { medical office,resting room,etc. } \\
\text { / 医務室、静養室等 }\end{array}$ \\
\hline $\begin{array}{l}\text { Exchange department } \\
\text { / 地域交流部門 }\end{array}$ & $\begin{array}{l}\text { community exchange space,interview space,etc. } \\
\text { / 地域交流スペース、面会室等 }\end{array}$ \\
\hline ceipt department / 収納部門 & receipt,store room,etc. / 収納、倉庫等 \\
\hline
\end{tabular}

\section{3. アンケート調査結果}

\section{$3-1$. 利用者の概要}

障害者支援施設の利用者の平均年齢・平均障害支援区分を Fig. 1 に示す。施設ごとの利用者の平均年齢は、50 歳以上 60 歳未満が 509 施設と最も多く全体の $48.6 \%$ を占め、平均は 52.1 歳である。 また、施設ごとの利用者の平均障害支援区分は、 5 以上が全体の $74.6 \%$ を占め、平均は 5.2 であった。

各施設の主な対象障害を Fig. 2 に示す。本調査では、各施設の主 に対象とする障害について、知的障害・身体障害・精神障害・難病 等・その他を選択肢として複数回答で伺い、施設ごとに分類を行っ た。分類は、知的障害と身体障害の有無に着目し、「知的障害のみ」 または「知的障害 + 身体障害以外 (精神障害・難病等)」とした施 設を「知的型」、同様に「身体障害のみ」または「身体障害十知的 障害以外」とした施設を「身体型」、知的障害十身体障害十その他 の障害」とした施設を「混合型」、その他の施設を「その他」とし た。その結果、「知的型」が最も多く644 施設、次いで「混合型」 が 318 施設、「身体型」が 173 施設であった。「その他」には精神障 害のみを対象とする 1 施設が該当した注9)。以降、主な対象障害（以 下、「対象障害」とする）による分析を行う際には、この分類を用 
いることとする。

\section{$3-2$. 施設建物の概要}

障害者支援施設の開設年と建設年を Fig. 3 に示す。全体の $70.0 \%$ を占める 804 施設が 1970 年代から 1990 年代に開設している。また、 開設施設数と建設施設数の差より、2010 年代には約 100 施設が建 替えを行っており、障害者支援施設の建替えが進んでいる状況が分 かる。建替えを行ったことがある施設は全体の $30.9 \%$ を占め、特 に 1980 年以前に開設された施設では $76.4 \%$ が建替えを行っている。 一方、1980 年以降に開設された施設の建替え実施割合は $10.4 \%$ で あり、今後 1980 年代・1990 年代に開設された施設の建替えも多く 行われると考えられる (Fig. 4)。

施設建物の立地状況について、Fig. 5 に示す。人口集中地区（D I D ） 注 10$)$ 内に立地する施設は全体の約 $13.1 \%$ であり、多くの障害 者支援施設が D I D外に立地する。

\section{$3-3$. 運営状況・支援の概要}

施設入所支援定員の分布を Fig. 6 に示寸。 50 人以上 60 人未満の 施設が 339 施設と最も多く、全体の $29.5 \%$ を占める。一方、定員 が 100 人以上の大規模施設も 51 施設存在する。また、施設の建設 年による、施設入所支援・生活介護 ・ 短期入所の定員の変遷を Fig. 7 に示寸。全体の平均は施設入所支援 53.3 人、生活介護 54.5 人、 短期入所 4.3 人である。施設入所支援定員は 1970 年代に建設され た施設が 63.6 人と最大であり、1980 年代以降に建設された施設で
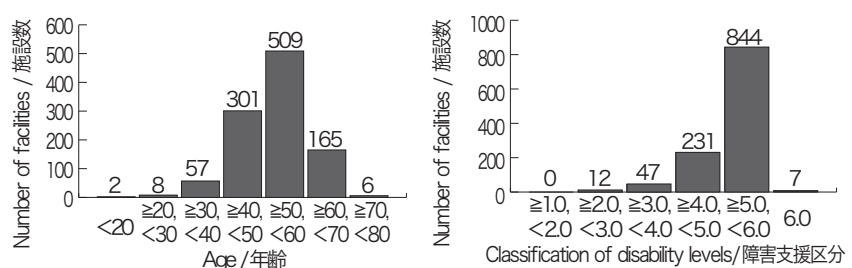

Fig. 1 Average age and classification of disability levels/ 平均年齢. 平均障害支援区分

Other : only mental disability / その他 : 精神のみ (1) Other : only mental disability /
Physical disability type / 身体型

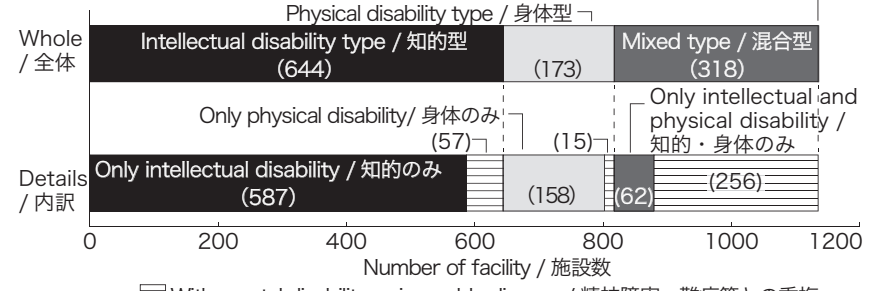

国With mental disability or incurable disease / 精神障害・難病等との重複

Fig. 2 Types of disability mainly covered / 主な対象障害

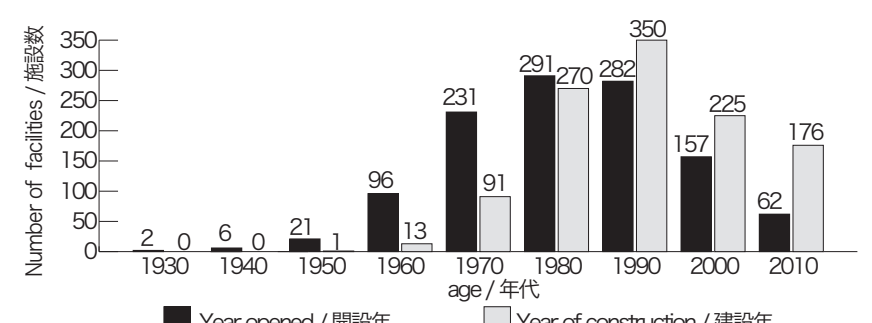

Year opened/開設年
Fig. 3 Year opened and Year of construction / 開設年と建設年

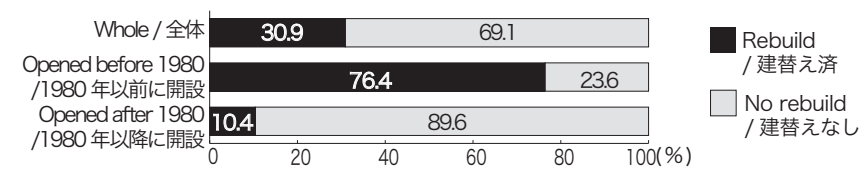

Fig. 4 Implementation status of rebuilding / 建替えの実施状況
は約 50 人で推移している。また、生活介護定員の推移も施設入所 支援の定員と同じ傾向にある。

施設の位置付け（どのような方のための住まいか）について、6 項目と「その他」への該当・非該当を聞いた結果を Fig. 8 に示す。「最 重度の障害により、身体介助を伴う手厚い支援が必要な方のための 住まい」 $(59.0 \%) ・ 「$ 加齢による機能低下が著しい方に向けた落ち 着いた暮らしを送るための住まい」（57.5\%）等、重度・高齢の障 害者に対する生活支援を行う施設としての項目が上位である。ま た、「近親者が少ない等、地域での生活が難しい方のための住まい」 に該当する施設が $50.4 \%$ である一方で、「グループホームやアパー トでの暮らしに向けた一時的な住まい」に該当する施設は $15.8 \%$ であることから、現状では地域移行を推進する移行施設としてより も、生活施設としての位置付けが重視されていると考えられる。

支援単位の数と 1 単位あたりの平均人数について、Fig. 9 に示す。

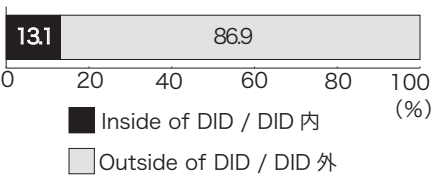

Fig. 5 Inside or outside DID / 立地の DID 内外

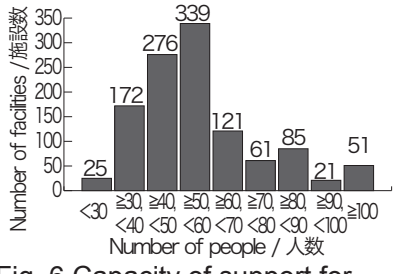

Fig. 6 Capacity of support for residential care/ 施設入所支援定員

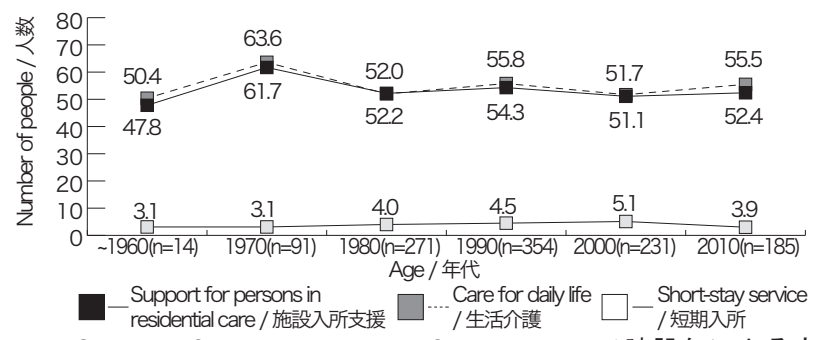

Fig. 7 Canges of capasity by year of construction / 建設年による定員 の変遷

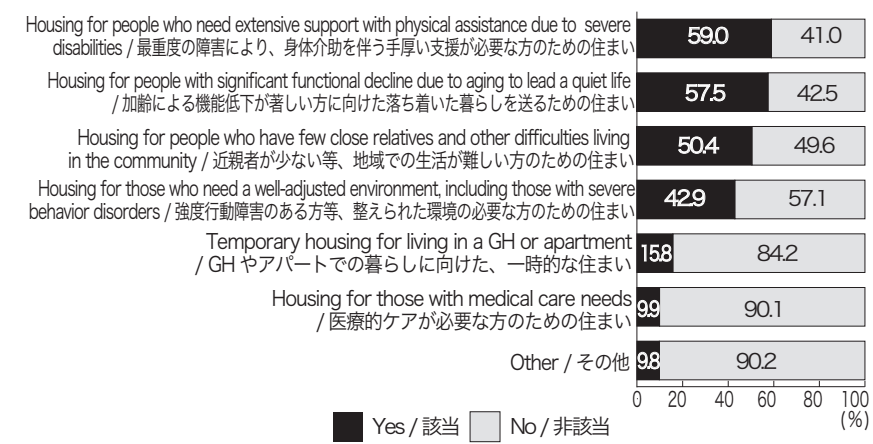

Fig. 8 Image of the target residents of the facility / 施設の位置付け

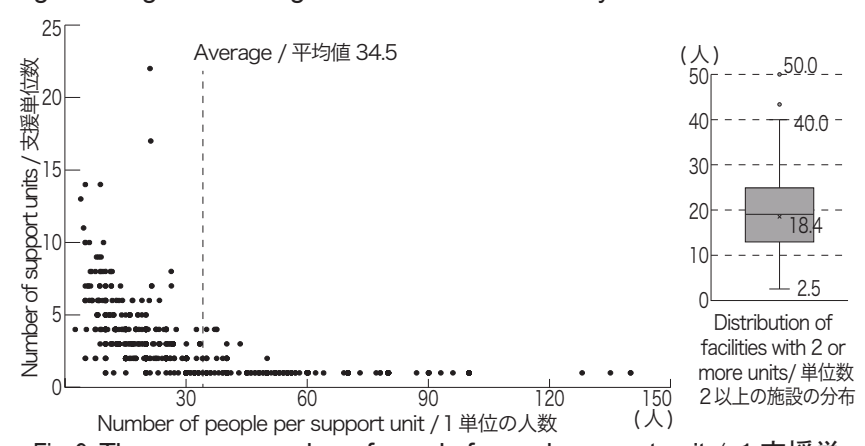

Fig. 9 The average number of people for each support unit / 1 支援単 位あたりの平均人数 
なお、本調査では「支援単位」を「夜間の生活の場において、入 居者をいくつかのグループに分けて支援すること」注11) と定義して いる。全体の 1 単位あたりの人数の平均值は 34.5 人である。また、 支援単位を分けている（単位数が 2 以上である）施設は $48.0 \%$ で あり、1単位あたりの平均人数は 18.4 人であった。

\section{$3-4$. 個室 $\cdot$ 生活単位の分割・昼夜分離の概要}

全個室・生活単位の分割・昼夜分離の実施状況を建設年代ごとに 示寸 (Fig. 10)。本調查では「生活単位の分割」を「いくつかの居

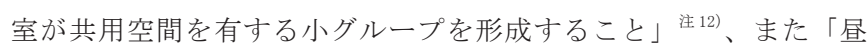
夜分離」を「利用者の日中の活動場所を居住空間と分けているこ と」と定義している。全体では、全個室は $24.4 \%$ 、生活単位の分 割は $16.9 \%$ 、昼夜分離は $73.0 \%$ の施設で実施されている。建設年 代による推移では、全個室は1980 年代に建設された施設が最も少 なく $2.6 \%$ であるが、以降増加し 2010 年代に建設された施設では $57.8 \%$ で実施されている。生活単位の分割と昼夜分離の実施割合 についても、1980 年代以降に建設された施設で増加傾向にあり、 2010 年代では生活単位の分割は $31.4 \%$ 、昼夜分離は $81.1 \%$ の施設 で実施されている。

障害者支援施設全体と、そのうち生活単位の分割を実施している 193 施設 ${ }^{i 3)}$ の居室定員の分布を Fig. 11 に示す。全体では $1.5-2.0$ 人以下の施設が最も多く 316 施設であり、平均は 1.8 人である。一 方、生活単位の分割を実施している施設では全個室施設が最も多く 97 施設であった。

生活単位の分割を実施している 193 施設における生活単位の定 員・分け方・設備について Fig. 12-Fig. 14 に示す。1 生活単位の 平均定員の分布については、 5 人以上 15 人未満の施設が全体の $75.1 \%$ を占め、平均は 11.1 人である（Fig. 12）。また、生活単位 の定員が 10 人以下と定められる高齢者施設や障害者グループホー ムと比べ、10人を超える大規模な生活単位の施設が全体の半数を 超える点が特徵的である。生活単位の分け方（性別・障害の特性・ 障害の程度・年齢) と設備（トイレ・リビング・キッチン・浴室） について、該当・非該当を聞いた結果を示す（Fig. 13,14）。全生活 単位に共通して設けられている生活単位の分け方の基準は、「性別」

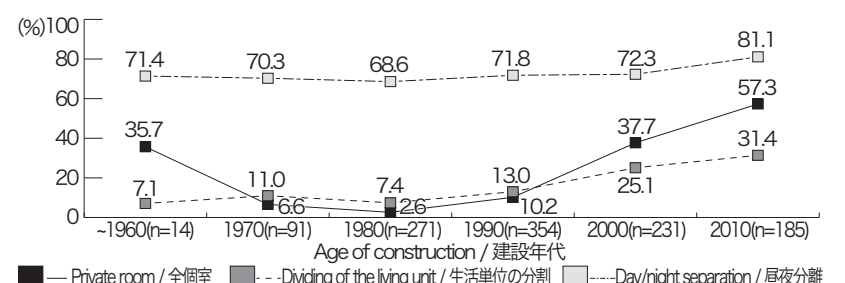

Fig. 10 Canges in introduction of private room, dividing of the living units, and day/night separation by year of construction / 建設年による 個室・生活単位の分割・昼夜分離の実施状況の変遷

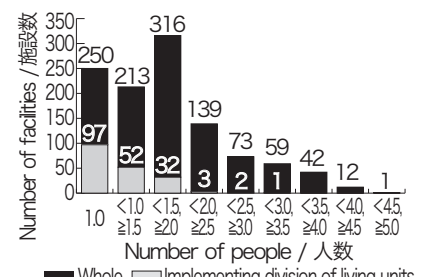

Whole $\square$ Implementing division of living units

Fig. 11 Capacity of a bed room / 居室定員

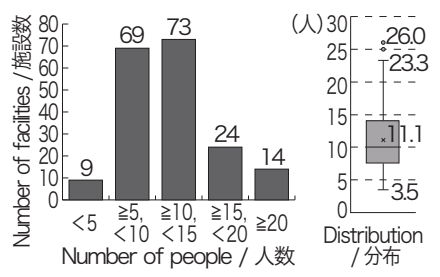

Fig. 12 The average number of people per living unit/生活単位の平 均定員

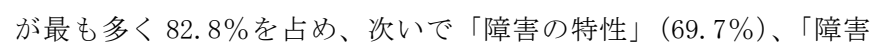
の程度」 $(55.9 \%) 、 「$ 年齢」 $(49.5 \%)$ であった。なお性別のみで生 活単位を分けている施設は 27 施設 $(14.0 \%)$ である。性別分離は、 居住性の向上よりは, 同性介助の容易性のために行われていると考 えられる。また、年齢については、「生活単位による」とする施設 が $47.9 \%$ と他の項目よりも多い。また、生活単位内の設備について、 約 90\%の施設で「トイレ」「リビング」を生活単位内に設けているが、 「キッチン」「浴室」は約 $60 \%$ であった。これらの設備は複数単位 で共有、または居住の場と分けて設けている場合もあると考えられ る。

\section{4. アンケート調査の分析}

\section{4-1. 対象障害による利用者の状況の比較}

障害者支援施設における対象障害による利用者の状況を比較する ため、利用者の平均年齢と平均障害支援区分を対象障害別にクラス カル・ウォリス検定にて比較した。結果、平均年齢について、身体 型が最も高く 57.0 歳、次いで混合型が 54.1 歳、知的型が 49.6 歳 であり、各対象障害に有意差がみられた。一方、平均障害支援区分 については有意差が示されなかった（Fig. 15）。

\section{4-2. 対象障害による支援方針の比較}

施設の位置付けについて、対象障害別に集計し、 $x^{2}$ 検定を行っ た結果 (Table 4)、知的型では「加齢による機能低下が著しい方に 向けた落ち着いた暮らしを送るための住まい」「強度行動障害のあ る方等、整えられた環境の必要な方のための住まい、身体型・混 合型では「最重度の障害により、身体介助を伴う手厚い支援が必要 な方のための住まい」「医療的ケアが必要な方のための住まい」と の回答が有意に多い。利用者の平均年齢が低い知的型が「加齢によ る機能低下が著しい」方に向けた施設に該当し、平均年齢が高い身 体型が該当しない理由としては、知的障害の早期の高齢化の影響が

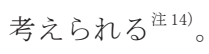

日中活動における支援の方針について、Fig. 16 に示す。活動プ

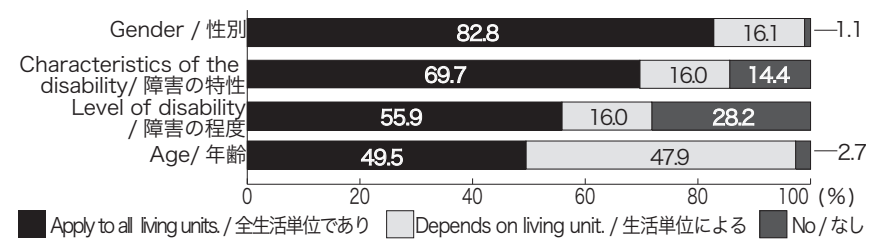

Fig. 13 How to divide the living units / 生活単位の分け方

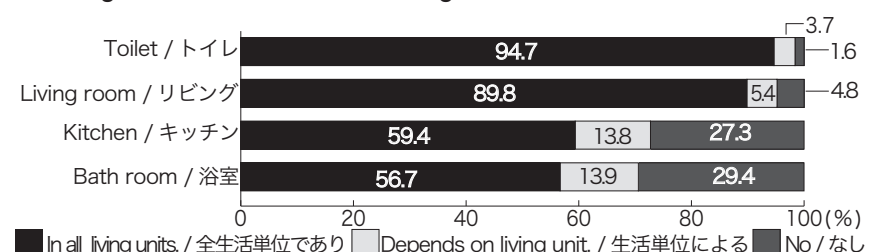

Fig. 14 Equipment of the living unit / 生活単位の設備
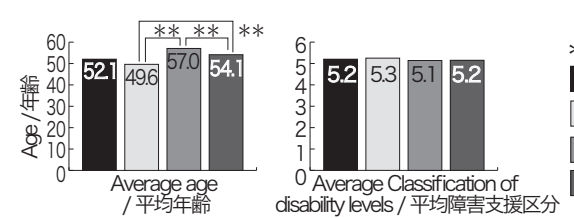

$$
\begin{aligned}
& * *: p<.01 \\
& \text { Whole / 全体 } \\
& \square \text { Intellectual disability type/知的型 } \\
& \square \text { Physical disability type / 身体型 } \\
& \square \text { Mixed type / 混合型 }
\end{aligned}
$$

Fig. 15 Comparison on average age and classification of disability levels / 利用者の平均年齢・平均障害支援区分の比較 
Table 4 Comparison of facility positioning by disability / 対象障害による施設の位置付けの比較

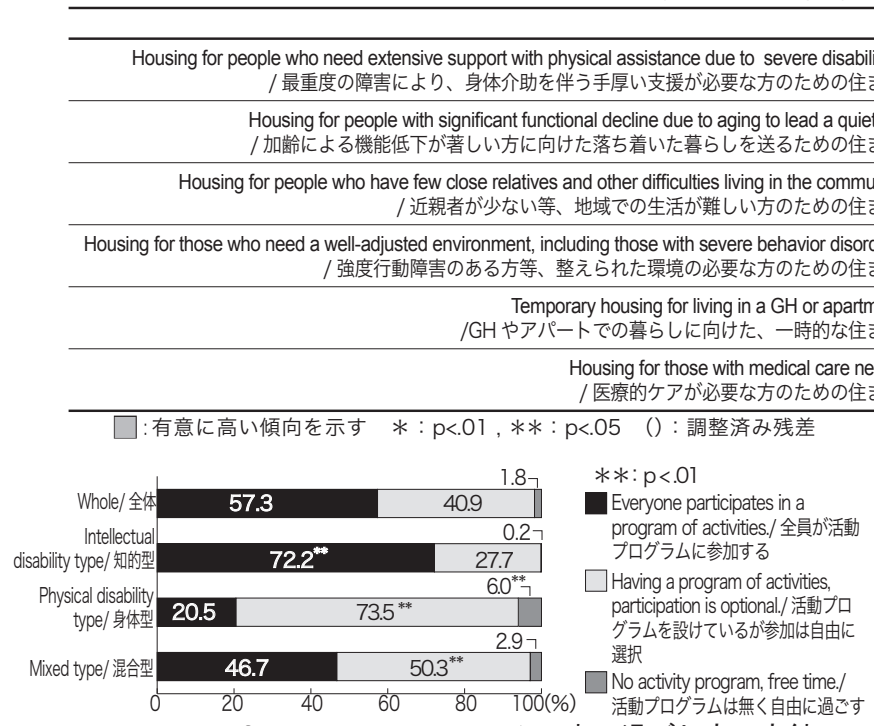

Fig. 16 Policy for Daytime Activities / 日中の過ごし方の方針

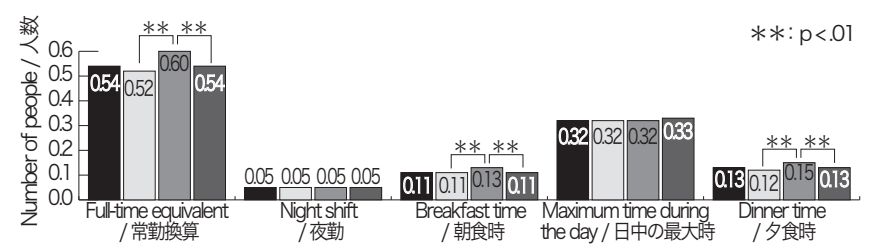

Whole/全体 $\square$ intellectual disability type/知的型 $\square$ Physical disability type/身体型 $\square$ Mixed type/混合型

Fig. 17 Number of staff per person / 1 人あたりの職員数

ログラムを設けていると回答した施設が全体の $98.2 \%$ 占めた。 うち、「全員が活動プログラムに参加する方針」が $57.3 \%$ 、「活動 プログラムへの参加を自由に選択する方針」が $40.9 \%$ である。対 象障害別に集計し $x^{2}$ 検定を行った結果、知的型は全員参加、身体 型・混合型は参加自由が有意に多い傾向がみられた。また、身体型 では他の障害型よりも「活動プログラムは無く自由に過ごす方針」 と回答した割合が大きい。

\section{4-3．対象障害による支援体制の比較}

施設入所支援と短期入所の利用者 1 人あたり ${ }^{\text {注 }}{ }^{15)}$ の常勤換算職員 数 - 1 日の時間帯別（夜勤 - 朝食時 $\cdot$ 日中最大時 - 夕食時）の職員 数を Fig. 17 に示す。常勤換算職員数について、全体の平均は 0.54 人であった。クラスカル・ウォリス検定にて比較したところ、身 体型が 0.60 人、次いで混合型が 0.54 人、知的型が 0.52 人であり、 身体型と混合型・知的型に有意差がみられた。1 日の時間帯別職員 数は、朝食時 $\cdot$ 夕食時の項目で身体型が知的型・混合型に比べ有意 に多い結果となったが、夜勤数と日中の最大職員数については有意 な差は示されなかった。

居住の場における支援単位の平均人数について、クラスカル・ウォ リス検定の結果、身体型が最も規模が大きく 42.6 人、次いで混合 型が 37.3 人、知的型が 30.5 人であった（Fig. 18）。

\section{4-4. 対象障害による建築構成の比較}

居室定員について、Fig. 19 に示す。全体の平均は 1.77 人である。 クラスカル・ウォリス検定の結果より身体型 (1.96 人) と知的型 （1.71 人）に差がみられ、知的型は有意に居室定員が少ない。

昼夜分離の実施について、Fig. 20 に示す。 $\chi^{2}$ 検定を行った結果、 身体型は昼夜分離を実施していない傾向がみられた。Fig. 16 で示

\begin{tabular}{|c|c|c|c|}
\hline & Intellectural disabilitytype/ 知的型 & Physical disabilitytype/身体型 & Mixed type / 混合型 \\
\hline Yes / 該当 & $326(-6.5)^{* *}$ & $136(5.6)^{* *}$ & $208(2.7)^{* * *}$ \\
\hline No / 非該当 & $315(6.5)^{* *}$ & $37(-5.6)^{* *}$ & $110(-2.7)^{* *}$ \\
\hline Yes / 該当 & $391(2.6)^{* *}$ & $64(-6.0)^{* *}$ & 198(1.9) \\
\hline No / 非該当 & $250(-2.6)^{* *}$ & $109(6.0)^{* *}$ & $120(-1.9)$ \\
\hline Yes / 該当 & $319(-0.3)$ & $78(-1.5)$ & $171(1.5)$ \\
\hline No / 非該当 & $322(0.3)$ & $95(1.5)$ & $147(-1.5)$ \\
\hline Yes / 該当 & $364(10.5)^{* *}$ & $9(-11.0)^{* * *}$ & $117(-2.8)^{* *}$ \\
\hline No / 非該当 & $277(-10.5)^{* * *}$ & $164(11.0)^{* *}$ & $201(2.8)^{* *}$ \\
\hline Yes / 該当 & $100(0.0)$ & $27(0.0)$ & $50(0.1)$ \\
\hline No / 非該当 & $541(0.0)$ & $146(0.0)$ & $168(-0.1)$ \\
\hline Yes / 該当 & $33(-6.3)^{* *}$ & $39(5.9)^{* *}$ & $42(2.2)^{*}$ \\
\hline No / 非該当 & $608(6.3)^{* *}$ & $134(-5.9)^{* *}$ & $276(-2.2)^{*}$ \\
\hline
\end{tabular}

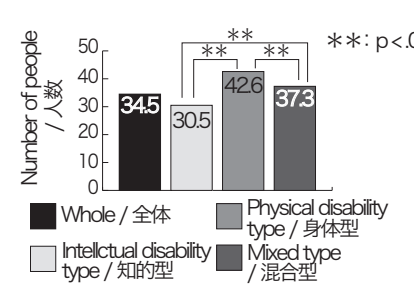

Fig. 18 Size of support unit/ 支援単位の規模

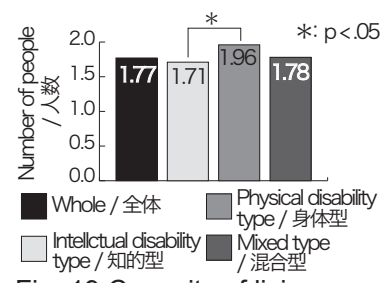

Fig. 19 Capacity of living room / 居室定員

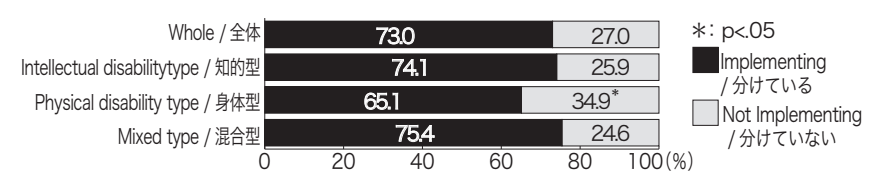

Fig. 20 Implementation of the day/night separation / 昼夜分離

\begin{tabular}{|c|c|c|c|}
\hline Whole /全体 & 16.9 & 83.1 & $* *: p<.01, *: p<05$ \\
\hline Intellectual disability type / 知的型 & $21.1^{\mathrm{m}}$ & 78.9 & \\
\hline Physical disability type / 身体型 & 8.7 & $91.3^{* *}$ & \\
\hline Mixed type / 混合型 & 129 & $87.1^{*}$ & $\begin{array}{l}\text { Not provide } \\
\text { / 実施していな }\end{array}$ \\
\hline
\end{tabular}

Fig. 21 Implementation of dividing of the living units / 生活単位の分割

した、身体型は他の障害型よりも「プログラムを設けず自由に過ご す」との日中活動の方針が施設計画にも表れていると考えられる。

生活単位の分割の実施についても、 $\chi^{2}$ 検定を行った結果、知的 型は生活単位の分割を実施している傾向、身体型・混合型は実施し ていない傾向がみられた (Fig. 21)。

4-5. 対象障害による職員の意向の比較

日中活動スペースの過不足に関する職員の意向について、Fig. 22 に示す。「十分である」とした施設は全体の $48.8 \%$ である。対象障 害別に $\chi^{2}$ 検定にて比較した結果、知的型で「不足している」、身 体型・混合型で「十分である」との回答が有意に多い。活動プログ ラムに利用者全員が参加する傾向がある知的型では、日中活動ス ペースが日中生活の場として用いられ、より面積的な充実が求めら れていること、また活動プログラムへの参加は利用者が自由に選択 する傾向がある身体型・混合型では、日中生活の場として日中活動 スペースが用いられることも少なく、面積拡充の要望も少ないと解 釈できる。

次に、居住の場において支援単位を分けている 552 施設について、 今後の支援単位の規模に関する意向を Fig. 23 に示す。「現状のまま が良い」が最も多く、全体の $57.2 \%$ を占めた。また、複数回答 $(2.5 \%)$ は、「現状のままが良い」「減らしたい」「バリエーションが欲しい」 の組み合わせであり、増やしたい」という回答は含まれなかった。 意向を選択した理由について、自由記述の一部をTable 5 に示す。 職員数・職員配置や利用者への個別対応といった支援に関寸る意見 が多くみられた。特に、「現状のままが良い」とした施設では、理 
由として利用者と職員の人数のバランスが適当であるという意見が ある一方で、現状の職員数や建物の構造により支援単位の規模を変 更することが困難であるため現状維持を選択したという消極的な意 見もみられた。また、現状のままが良い」「減らしたい」「バリエー ションが欲しい」との回答の有無を、対象障害別に $\chi^{2}$ 検定により 比較した。結果、知的型は「減らしたい」「バリエーションが欲しい」、 混合型は「現状のままが良い」とする傾向がみられた（Fig. 24）。

施設建物の改善点や必要な機能について Table 6 に示す。自由 意見としてあげられた上位 12 項目について、回答があった知的型 488 施設・身体型 106 施設・混合型 218 施設のうち、各項目につい て意見が示された施設の割合を示している。これら 12 項目は、施 設全体について「バリアフリー化 $(30.4 \%) 」 「$ 老朽化 $(8.2 \%) 」$ 等、 居住の場について「個室化 (25.3\%)」「生活単位の分割 $(5.6 \%) 」$ 等、活動の場について「室数・面積 $(4.7 \%)$ 、支援について「介 護機器の導入 $(9.7 \%) 」$ 等である。バリアフリー化や個室化に関す る要望は、各障害型に共通して多いが、特に知的型でバリアフリー 化が $36.3 \%$ 、浴室の改善が $21.3 \%$ と割合が高い。一方、身体型では、

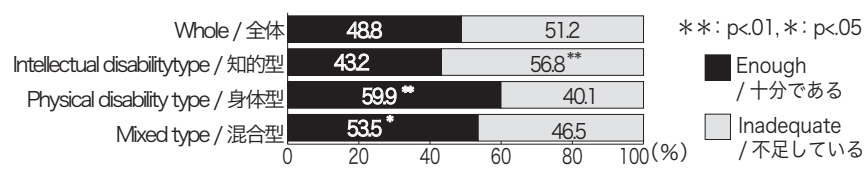

Fig. 22 Enough or inadequate area of the activity room / 活動室面積 の過不足

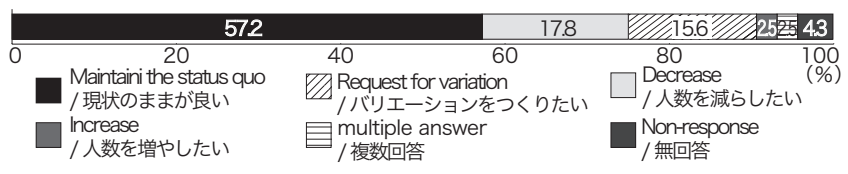

Fig. 23 Staff intentions regarding the size of the support unit / 支援単 位の規模に関する職員の意向

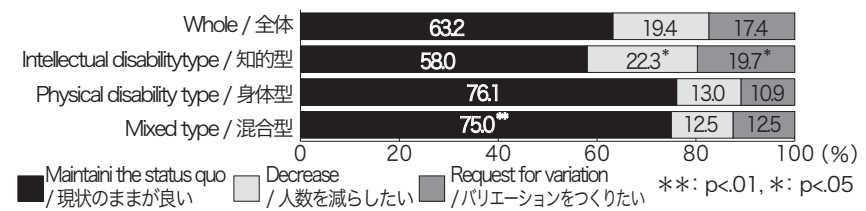

Fig. 24 Comparison on staff intentions regarding the size of the support unit / 対象障害による支援単位の規模に関する職員の意向の 比較
職員動線の改善が $9.4 \%$ 、介護機器の導入が $21.3 \%$ であり、支援に 関する改善が求められているという特徵がみられた。

\section{4-6. 個室ユニット型施設に関する分析}

全個室かつ生活単位の分割を実施し、生活単位の定員が 10 人以 下である 44 施設（以下、「個室ユニット型」とする）と、その他の 施設の支援体制について比較した ${ }^{\text {i⿱ }}{ }^{16)}$ 。1支援単位あたりの平均人 数・ 1 人あたり常勤換算職員数の比較を Fig. 25 に、 1 人あたり時 間帯別職員数の比較を Fig. 26 に示す。各比較には Mann-Whitney の U 検定を用いた。結果、個室ユニット型施設はその他の施設よりも 1 支援単位の規模が小さく、1 人あたりの常勤換算職員数と全ての 時間帯の職員数が多い結果となった。

\section{5. 平面構成調査の結果・分析}

平面構成調査の対象である 230 施設について、居室と活動室面積・ 日中活動空間と居住空間の施設構成・施設の部門別面積の調查を 行った ${ }^{\text {i⿱ } 17)}$ 。各調査のサンプル数を Table 7 に示す。

\section{5-1. 居室・活動室の面積}

利用者 1 人あたりの延床面積・居室面積・活動室面積を Fig. 27 に示す。全体の平均は、延床面積が $42.8 \mathrm{~m}^{2}$ 、居室面積が $10.7 \mathrm{~m}^{2}$ 、 活動室面積が $3.9 \mathrm{~m}^{2}$ であった。

居室面積について、対象障害別では知的型が $10.3 \mathrm{~m}^{2}$ 、身体型が $11.9 \mathrm{~m}^{2}$ 、混合型が $10.9 \mathrm{~m}^{2}$ であり、クラスカル・ウォリス検定より

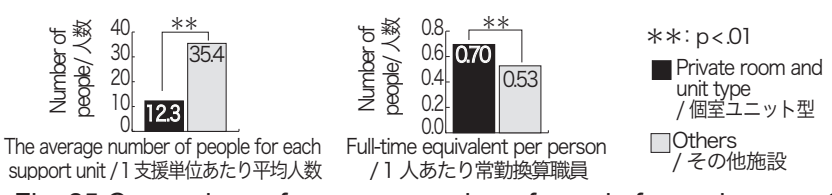

Fig. 25 Comparison of average number of people for each support unit and number of full-time equivalent staff between private room and unit type and others / 個室ユニット型とその他施設の支援単位平均人 数・常勤換算職員数の比較

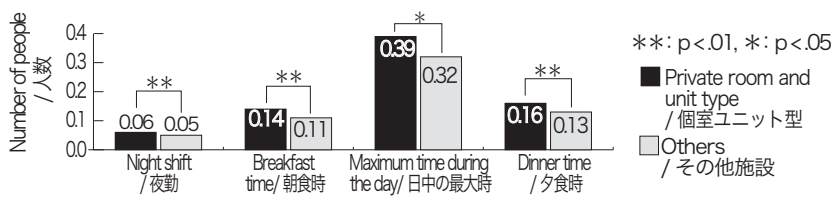

Fig. 26 Comparison of the number of staff per person by time of day between private room and unit type and others / 個室ユニット型と その他施設の時間帯別職員数の比較

Table 5 Reasons for the selection of support unit size intentions / 支援単位規模の意向の選択理由

\begin{tabular}{|c|c|}
\hline $\begin{array}{l}\text { 回答 } \\
\text { The status quo is good. } \\
\text { / 現状のままが良い }\end{array}$ & $\begin{array}{l}\text { - The balance between the number of users and staff and the living environment are appropriate. / 利用者と職員数のバランスや、生活環境が適当であるため } \\
\text { - Smaller units are preferable, but staffing will be difficult. / 小規模な単位が望ましいが、職員配置古困難になるため } \\
\text { D Difficult to change the building structure, room layout, and capacity. I 建物の構造や居室配置、定員を変更することが難しいため }\end{array}$ \\
\hline \multicolumn{2}{|c|}{$\begin{array}{l}\text { Request to decrease the number of people } \cdot \text { Difficult to respond at night. / 夜間の対応が大変であるため } \\
\qquad \text { /グループの人数を減らしたい } \cdot \text { To provide private and individualized care / 個室化、個別対応を行うため }\end{array}$} \\
\hline \multicolumn{2}{|c|}{$\begin{array}{l}\text { Request to increase the number of people · The current number of employees is less than the capacity. / 現員が定員に満たないため } \\
\text { / グループの人数を增やしたい · To increase capacity because there is a waiting list / 待機者がいので定員を增やしたいため }\end{array}$} \\
\hline $\begin{aligned} \text { Request for variation } \\
\text { バリエーションが欲しい }\end{aligned}$ & $\begin{array}{l}\text { - To provide individualized support tailored to the characteristics of users / 利用者の特性に合わせた個別的な支援を行うため } \\
\text { To consider the user's age, compatibility, etc. / 利用者の年齢、相性などを考慮するため }\end{array}$ \\
\hline
\end{tabular}

Table 6 Improvements to the facility and necessary functions / 改善点・必要な機能

\begin{tabular}{|c|c|c|c|c|c|c|c|c|c|c|c|c|}
\hline & \multicolumn{6}{|c|}{$\begin{array}{l}\text { Aboutthe entire facility } \\
\text { /施設全体について }\end{array}$} & \multicolumn{3}{|c|}{$\begin{array}{l}\text { About living space } \\
\text { / 居住の場について }\end{array}$} & \multirow{2}{*}{$\begin{array}{l}\text { About activity } \\
\text { space / 活動 } \\
\text { の場について } \\
\text { Lack of room } \\
\text { and space / } \\
\text { 室数・面積 }\end{array}$} & \multicolumn{2}{|c|}{$\begin{array}{l}\text { About support of stuff } \\
\text { /支援について }\end{array}$} \\
\hline & $\begin{array}{c}\text { barrier-free } \\
\text { / バリアフ } \\
\text { リー }\end{array}$ & $\begin{array}{l}\text { Toilet } \\
\text { /トイレ }\end{array}$ & $\begin{array}{l}\text { Bathroom } \\
\text { / 浴室 }\end{array}$ & $\begin{array}{c}\text { Aging of the } \\
\text { building / 老朽 } \\
\text { 化 }\end{array}$ & $\begin{array}{l}\text { Lack of area } \\
\text { / 面積不足 }\end{array}$ & $\begin{array}{c}\text { Individual } \\
\text { Space / 個別 } \\
\text { スペース } \\
\end{array}$ & $\begin{array}{l}\text { Private room } \\
\text { / 個室化 }\end{array}$ & $\begin{array}{l}\text { Dividing of the } \\
\text { living units / } \\
\text { 生活単位の分割 }\end{array}$ & $\begin{array}{c}\text { Separating by } \\
\text { characteristics } \\
\text { / 住み分け } \\
\end{array}$ & & $\begin{array}{c}\text { Staff flow } \\
\text { / 職員動線の } \\
\text { 改善 } \\
\end{array}$ & $\begin{array}{l}\text { Nursing care } \\
\text { equipment / 介 } \\
\text { 護機器の導入 } \\
\end{array}$ \\
\hline Intellectural disability type / 知的型 & $36.3 \%$ & $9.6 \%$ & $21.3 \%$ & $6.8 \%$ & $4.5 \%$ & $8.0 \%$ & $26.8 \%$ & $6.6 \%$ & $4.9 \%$ & $5.1 \%$ & $2.0 \%$ & $5.3 \%$ \\
\hline Physical disability type/ 身体型 & $12.3 \%$ & $5.7 \%$ & $16.0 \%$ & $12.3 \%$ & $5.7 \%$ & $5.7 \%$ & $23.6 \%$ & $2.8 \%$ & $2.8 \%$ & $3.8 \%$ & $9.4 \%$ & $21.7 \%$ \\
\hline Mixed type / 混合型 & $24.8 \%$ & $12.4 \%$ & $17.4 \%$ & $8.7 \%$ & $2.3 \%$ & $7.3 \%$ & $21.6 \%$ & $4.6 \%$ & $5.0 \%$ & $4.1 \%$ & $3.7 \%$ & $13.3 \%$ \\
\hline Whole / 全体 & $30.4 \%$ & $10.1 \%$ & $19.8 \%$ & $8.2 \%$ & $4.2 \%$ & $7.6 \%$ & $25.3 \%$ & $5.6 \%$ & $4.7 \%$ & $4.7 \%$ & $3.5 \%$ & $9.7 \%$ \\
\hline
\end{tabular}


身体型と知的型に有意差がみられた。また、居室面積の建設年代に よる変遷を Fig. 28 に示す。建設年代による変遷では、1980 年代に 建設された施設が最も居室面積が小さく $8.8 \mathrm{~m}^{2}$ であるが、以降に建 設された施設では居室面積水準の向上がみられ、2010 年代に建設 された施設の平均は $12.7 \mathrm{~m}^{2}$ である。障害者支援施設の居室面積基 準である $9.9 \mathrm{~m}^{2} に$ 満たない施設がみられるが、旧法上の施設として 開設された後に障害者支援施設に移行する際に経過措置 ${ }^{\text {注 }}$ を利用 しているものが含まれているためと考えられる。

活動室については、昼夜分離を行っている場合は入居者の日中の 主な滞在場所となることが予想され、必要とされる面積も大きいこ とが予想される。このような想定のものと、まず対象障害別で比較 した結果、知的型が $3.9 \mathrm{~m}^{2}$ 、身体型が $4.1 \mathrm{~m}^{2}$ 、混合型が $3.7 \mathrm{~m}^{2}$ であり、 有意差はみられなかった（Fig. 27）。一方、Mann-Whitney のU 検定 より、昼夜分離を実施している施設は実施していない施設よりも活 動室面積が有意に大きい結果となった（Fig. 29）。

\section{$5-2$. 活動空間と居住空間の構成}

昼夜分離を実施する際に用いられる施設構成を明らかにするた め、居室と活動室の位置関係に着目し、棟を基準とする分類を行っ た（Table 8)。結果、活動空間と居住空間が分けられていない「一 体型」は 29.3\%であり、アンケート調查結果（Fig. 20）との傾向 の一致がみられた。昼夜分離を実施している施設においては、居室 と活動室が 1 棟に含まれエリアや階により両者を分離している「集 約型」が $20.1 \%$ 、複数の居住棟と活動棟に分かれる「分散型」が $31.4 \%$ と多い傾向にある。その他、居住棟が 1 棟で活動棟と分かれ ている「分棟型」が 9.4\%、居住と活動の分離方法が混在している 「混在型」が $11.8 \%$ であった。集約型では階層タイプが多く、分散 型では平屋タイプが多い。また、集約型と分散型を立地のD I D内 外について $\chi^{2}$ 検定により比較した結果 (Table 9)、集約型はD I D内に、分散型はD I D 外に立地する傾向が有意に高いことから、 敷地面積が小さい都市型の施設では集約型が、敷地に余裕がある施 設では分散型が選択されていると考えられる。なお、建設年代や対 象障害による棟構成の傾向はみられなかった。

\section{5 - 3. 部門面積構成}

ユニットケアを実施する施設や個室型の施設の面積構成の特徴を 明らかにするため、個室ユニット型施設・個室従来型注 199 施設・多 床室型施設の各建築タイプより、対象障害・施設入所支援と短期入 所の合計定員規模・個室率をなるべくマッチングさせた各 12 施設、 計 36 施設をサンプリングし、部門別の面積を計測した上で部門面
Table 7 Number of samples of floor plan survey / 平面構成調査のサ

\begin{tabular}{|c|c|c|}
\hline & $\begin{array}{l}\text { Number of samples } \\
\text { /サンブル数 }\end{array}$ & Remarks / 供考 \\
\hline $\begin{array}{l}\text { Living room area / 居室面積 } \\
\end{array}$ & 226 & Including storage in the living room / 居室内の叫納を含艺 \\
\hline Activity room area /活動室面績 & 184 & Not including the daycare part/通所部分を含まない \\
\hline $\begin{array}{l}\text { Composition of Activityliving } \\
\text { separation / 昼液分雒構成 }\end{array}$ & 210 & - \\
\hline $\begin{array}{l}\text { Area composition by department/ } \\
\text { 部門面皟棈成 }\end{array}$ & 36 & $\begin{array}{l}12 \text { private room and unit-type facilities, } 12 \text { private room } \\
\text { and conventitional facilities, } 12 \text { multi-bedroom facilities / / / } \\
\text { 室ユニット型、個室從来型、多床室型各 } 12 \text { 施設 }\end{array}$ \\
\hline
\end{tabular}

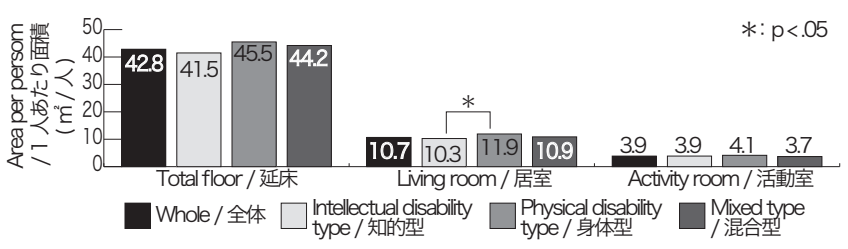

Fig. 27 Size of the area / 延床 · 居室 · 活動室の 1 人あたり面積

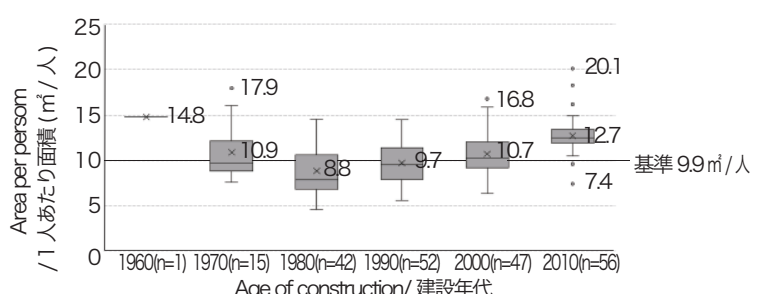

Fig. 28 Changes of living room area per person by year of construction/ 居室面積の建設年による変遷

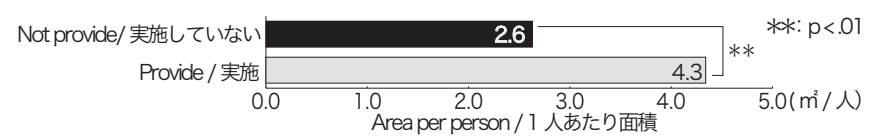

Fig. 29 Comparison by whether or not Activity/Living space separation is provided/昼夜分離の実施有無による活動室面積の比較

Table 8 Composition of day/night separation / 昼夜分離の構成方法

\begin{tabular}{|c|c|c|c|c|c|}
\hline \multirow{4}{*}{$\begin{array}{l}\text { Composition of } \\
\text { day/night } \\
\text { separation } \\
\text { / 昼夜分離の構成 }\end{array}$} & & \multicolumn{2}{|c|}{$\begin{array}{l}\text { Living department in one building } \\
\text { / 居住が } 1 \text { 棟 }\end{array}$} & \multicolumn{2}{|c|}{$\begin{array}{l}\text { Living department in multiple buildings } \\
\text { / 居住力腹数棟 }\end{array}$} \\
\hline & $\begin{array}{l}\text { Integral type } \\
1 \text { - 体型 }\end{array}$ & $\begin{array}{l}\text { Aggregate type } \\
\text { /集約型 }\end{array}$ & $\begin{array}{l}\text { Annexed type } \\
\text { / 分棟型 }\end{array}$ & $\begin{array}{l}\text { distributed type } \\
\text { / 分散型 }\end{array}$ & $\begin{array}{l}\text { Mixed type } \\
\text { / 混在型 }\end{array}$ \\
\hline & 昼夜分離なし & & & & \\
\hline & $\begin{array}{l}\text { ※居住棟の数に } \\
\text { よらない }\end{array}$ & & $\begin{array}{l}\text { ※活動棟が゙複数 } \\
\text { の場合を含 }\end{array}$ & $\begin{array}{l}\text { ※活動棟が複数 } \\
\text { の場合を含む }\end{array}$ & ※活動の入る棟が \\
\hline One-story / 平屋 & $35(17.1 \%)$ & $10(4.9 \%)$ & $11(5.4 \%)$ & $45(22.1 \%)$ & $15(7.4 \%)$ \\
\hline Multiple-story / 階層 & $25(12.2 \%)$ & $31(15.2 \%)$ & $4(2.0 \%)$ & 19(9.3\%) & 9(4.4\%) \\
\hline Summery / 合計 & $60(29.3 \%)$ & $41(20.1 \%)$ & $15(7.4 \%)$ & $64(31.4 \%)$ & $24(11.8 \%)$ \\
\hline
\end{tabular}

Living department / 居住部門 $\square$ Acyivity department / 活動部門

Table 9 Composition of Activity/Living separation by inside or outside of DID／昼夜分離構成方法の DID 内外による比較

\begin{tabular}{ccc}
\hline & Inner DID /DID 内 & Outside DID /DID 外 \\
\hline Aggregate type / 集約型 & $10(2.4)^{*}$ & $31(-2.4)^{*}$ \\
\hline Distributed type / 分散型 & $5(-2.4)^{*}$ & $59(-2.4)^{*}$ \\
\hline : 有意に高い傾向を示す $\quad *: p<.05 \quad(）$ : 調整済み残差
\end{tabular}

Table 10 Overview of samples / 調査対象施設の概要

\begin{tabular}{|c|c|c|c|c|c|c|c|c|c|c|c|c|c|c|c|c|c|c|}
\hline \multirow[b]{2}{*}{$\begin{array}{l}\text { Types of disability } \\
\text { / 対象障害 }\end{array}$} & \multicolumn{6}{|c|}{ Private room and unit-type facilities/個室ユニット型 } & \multicolumn{6}{|c|}{ Private room and conventional facilities/個室従来型 } & \multicolumn{6}{|c|}{ Multi-bedroom facilities/多床室型 } \\
\hline & \begin{tabular}{|} 
Case \\
/事例
\end{tabular} & $\begin{array}{l}\text { Capacity } \\
\text { / 定員 }\end{array}$ & $\begin{array}{c}\text { Year of } \\
\text { constuction } \\
/ \text { 建設年代 }\end{array}$ & $\begin{array}{l}\text { Private } \\
\text { Room } \\
\text { Rate } \\
\text { / 個室率 }\end{array}$ & $\begin{array}{c}\text { Activity/ } \\
\text { Living } \\
\text { separation } \\
\text { / 宣夜分離 }\end{array}$ & $\begin{array}{c}\text { Off-site activity } \\
\text { locations } \\
\text { / 敷地外の活 } \\
\text { 動場所 }\end{array}$ & $\begin{array}{l}\text { Case } \\
\text { /事例 }\end{array}$ & $\begin{array}{l}\text { Capacity } \\
\text { / 定員 }\end{array}$ & $\begin{array}{c}\text { Year of } \\
\text { constuction } \\
\text { /建設年代 }\end{array}$ & $\begin{array}{l}\text { Private } \\
\text { Room } \\
\text { Rate } \\
\text { / 個室率 } \\
\end{array}$ & $\begin{array}{c}\text { Activity/ } \\
\text { Living } \\
\text { separation } \\
\text { / 飠夜分離 } \\
\end{array}$ & $\begin{array}{c}\text { Off-site activity } \\
\text { locations } \\
\text { / 敷地外の活 } \\
\text { 動場所 }\end{array}$ & $\begin{array}{l}\text { Case } \\
/ \text { 事例 }\end{array}$ & $\begin{array}{l}\text { Capacity } \\
\text { / 定員 }\end{array}$ & $\begin{array}{c}\text { Year of } \\
\text { constuction } \\
\text { /建設年代 }\end{array}$ & $\begin{array}{c}\text { Private } \\
\text { Room } \\
\text { Rate } \\
\text { / 個室率 } \\
\end{array}$ & $\begin{array}{c}\text { Activityl } \\
\text { Living } \\
\text { separation } \\
\text { / 苜夜分離 } \\
\end{array}$ & $\begin{array}{c}\text { Off-site activity } \\
\text { locations } \\
\text { /敷地外の活 } \\
\text { 動場所 }\end{array}$ \\
\hline \multirow{8}{*}{$\begin{array}{c}\text { Intellectural } \\
\text { disability type } \\
\text { /知的型 }\end{array}$} & $\mathrm{A}-1$ & 36 & 2000 & 100.0 & $\bigcirc$ & 0 & B-1 & 32 & 2010 & 100.0 & $\mathrm{O}$ & $\bigcirc$ & C-1 & 40 & 1980 & 0.0 & 0 & $\mathrm{O}$ \\
\hline & A-2 & 40 & 2000 & 100.0 & O & O & B-2 & 36 & 2010 & 100.0 & $\mathrm{O}$ & O & $\mathrm{C}-2$ & 43 & 2010 & 20.0 & $\mathrm{O}$ & $x$ \\
\hline & A-3 & 40 & 2010 & 100.0 & 0 & $x$ & B-3 & 40 & 2010 & 100.0 & 0 & 0 & C-3 & 44 & 1990 & 0.0 & 0 & $x$ \\
\hline & A-4 & 49 & 1990 & 100.0 & O & O & B-4 & 44 & 1990 & 100.0 & O & $x$ & $\mathrm{C}-4$ & 46 & 1980 & 0.0 & 0 & 0 \\
\hline & A-5 & 56 & 2000 & 100.0 & 0 & 0 & B-5 & 60 & 2000 & 100.0 & 0 & $x$ & C-5 & 52 & 1980 & 2.0 & $x$ & 0 \\
\hline & A-6 & 60 & 2000 & 100.0 & 0 & 0 & B-6 & 61 & 2000 & 100.0 & 0 & 0 & $\mathrm{C}-6$ & 55 & 1980 & 3.8 & 0 & $x$ \\
\hline & A-7 & 64 & 2010 & 100.0 & 0 & 0 & B-7 & 61 & 1980 & 100.0 & 0 & $x$ & C-7 & 56 & 1990 & 10.7 & $x$ & $\bigcirc$ \\
\hline & A-8 & 70 & 2010 & 100.0 & 0 & $x$ & B-8 & 63 & 2010 & 100.0 & 0 & $x$ & C-8 & 60 & 1990 & 10.8 & 0 & $x$ \\
\hline \multirow{2}{*}{$\begin{array}{l}\text { Physical disability } \\
\text { type / 身体型 }\end{array}$} & A-9 & 38 & 2000 & 100.0 & $x$ & 0 & B-9 & 35 & 2000 & 98.8 & 0 & 0 & C-9 & 44 & 1980 & 5.7 & 0 & 0 \\
\hline & $A-10$ & 68 & 2000 & 100.0 & 0 & 0 & B-10 & 60 & 2010 & 100.0 & 0 & $x$ & C-10 & 72 & 1990 & 18.9 & $x$ & $x$ \\
\hline \multirow{2}{*}{$\begin{array}{l}\text { Mixed type } \\
\text { /混合型 }\end{array}$} & A-11 & 44 & 2010 & 100.0 & 0 & 0 & B-11 & 44 & 2000 & 100.0 & 0 & 0 & C-11 & 42 & 1990 & 0.0 & 0 & 0 \\
\hline & A-12 & 90 & 2010 & 100.0 & 0 & $x$ & B-12 & 88 & 2010 & 100.0 & 0 & $x$ & C-12 & 80 & 1970 & 0.0 & 0 & $x$ \\
\hline
\end{tabular}


積構成に関する分析を行った。調査対象施設の概要をTable 10 に 示す。対象障害別では、知的型 24 施設、身体型 6 施設、混合型 6 施設である。

1 人あたりの居住部門・活動部門・共用部門・廊下部門面積と 1 人あたり延床面積の関係を Fig. 30 に示す。居住部門では多床室型、 共用部門では個室従来型・多床室型、廊下部門では全グループで、 $\mathrm{R}^{2} \geqq 0.5$ であり、延床面積との相関がみられた。一方、活動部門 についてはどのグループも相関がみられず、施設全体の面積規模と は無関係であることが示された。この理由については本稿の分析の 範囲を超えるが、おそらくは日中活動として活動室で行われる活動 内容の多様性が影響していると推察され、そのため求められる面積
規模を一義的に予測することは困難であると考えられる。

各事例の部門別の構成割合を Fig. 31 に、1 人あたり面積を Fig. 32 に示す。また、各タイプの面積構成割合の平均を Fig. 33 に示す。 個室型 24 施設と多床室型 12 施設の部門別の構成割合と 1 人あたり 面積を Mann-Whitney のU 検定により比較した結果、管理部門・サー ビス部門・医療部門の構成割合について多床室型が個室型よりも大 きく、地域交流部門の構成割合について個室型が多床室型よりも大 きい（Fig. 34）。また、1 人あたりの居住部門・共用部門・廊下部門・ 地域交流部門と延床の面積について、個室型が多床室型よりも大き いという結果が得られた（Fig. 35）。一方、個室型のうち個室ユニッ 卜型 12 施設と個室従来型 12 施設では、構成割合・1 人あたり面積
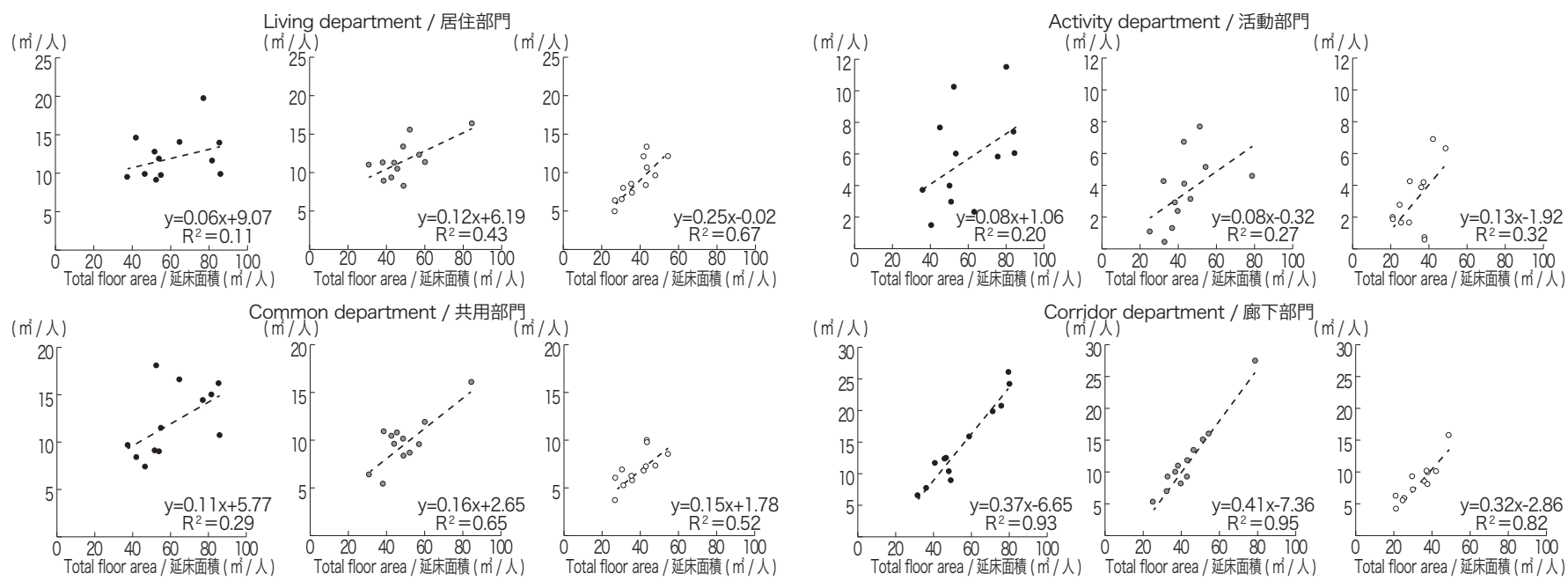

- Private room and unit type facilities / 個室ユニット型 OPrivate room and conventional facilities/個室従来型 OMulti-bedroom facilities / 多床室型

Fig. 30 Relationship between departmental area and total floor area per person / 1 人あたりの部門面積と延床面積の関係
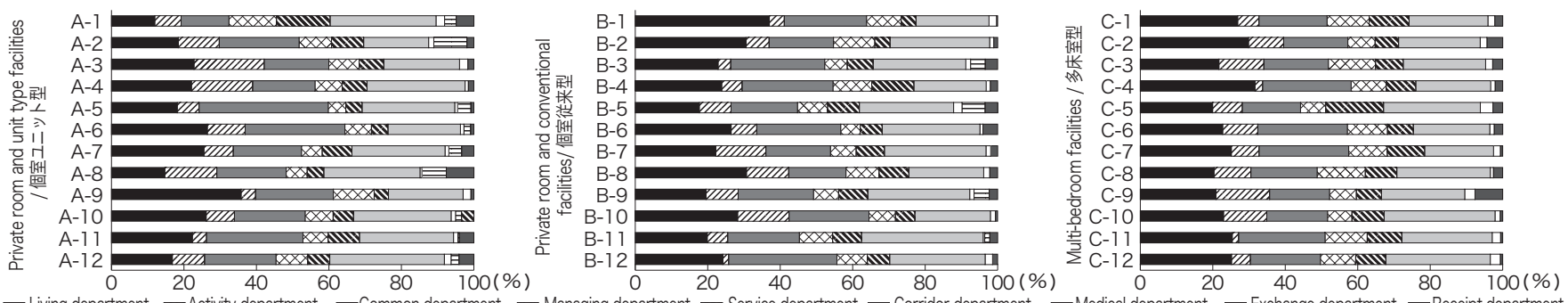

Living department $\mathbb{Z}$ Activity department $\square$ Common department Managing

Fig. 31 Area composition by department / 各事例の部門別の構成割合
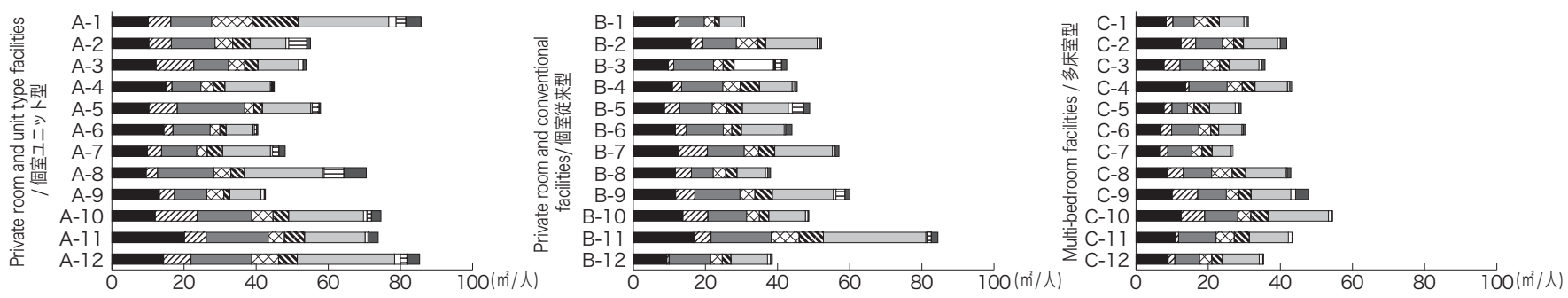

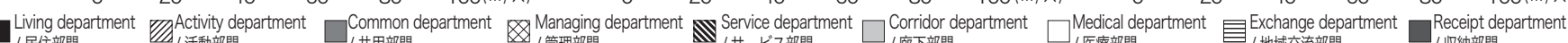

Fig. 32 Area per person by department / 各事例の部門別の 1 人あたり面積

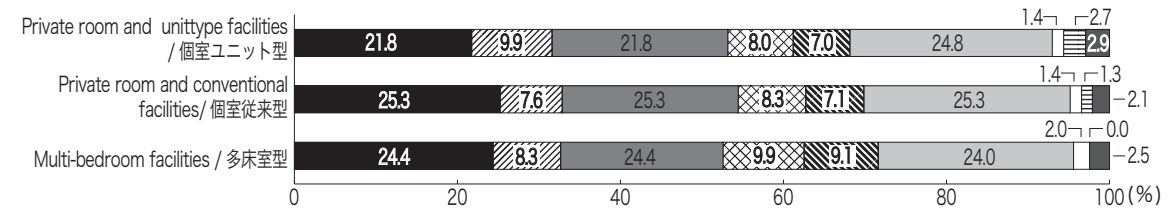

Living department Managing department $\square$ Medical department /居住部門 $\bigotimes_{/ \text {管理部門 }}$

Activity department $\mathbb{W}_{\text {Service department }}^{\text {Exchange department }}$

活動部門 /サービス部門

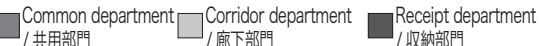

Fig. 33 Average area composition by department of each type / 各タイプの部門別構成割合の平均 


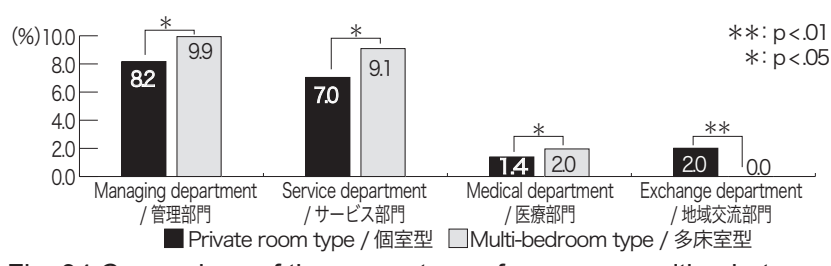

Fig. 34 Comparison of the percentage of area composition between the private and multi-bedroom types by department / 個室型 · 多床室 型の部門別構成割合の比較

共に有意差はみられなかった。

\section{6. 考察・まとめ}

\section{6-1. 対象障害ごとの支援の特徵}

本研究で行った対象障害による比較では、特に知的型と身体型の 傾向の違いが顕著であった。以下、両者の支援・建築構成における 傾向について考察する。まず支援の傾向について、知的型の施設は 施設の位置づけとして「強度行動障害のある方等、整えられた環境 の必要な方のための住まい」に有意に多く該当し（Table 4）、日中 の過ごし方は「全員が活動プログラムに参加する」割合が多く（Fig. 16)、昼夜分離も $74.1 \%$ 施設で実施されている (Fig. 20)。すなわち、 知的型の施設では加齢や障害の重度化が進展しても、日中活動や昼 夜分離など施設のプログラムや建築構成を通じ、夜間と日中の生活 を区分けし、「普通の」生活リズムの創出が目指されている。

次に身体型の施設について、施設の位置づけとしては「最重度の 障害により、身体介助を伴う手厚い支援が必要な方のための住ま い」「医療的ケアが必要な方のための住まい」に有意に多く該当し (Table 4)、日中の過ごし方は「活動プログラムはあるが参加は自由」 「活動プログラムは無い」割合が多く（Fig. 16）、昼夜分離は比較的 少ない（Fig. 20）。他方で、知的型の施設に比べ食事時の職員数が 多い傾向にあり（Fig. 17）、職員の意向として支援に関する改善が 多く示される（Table 6) ことからは、身体的介助が多く必要とさ れていることが示唆される。すなわち、身体型の施設では夜間・日 中を通じて、主に生活に不可欠な入浴や食事などの支援が提供され るという、いわば「高齢者施設」的な支援が行われている傾向にあ ると考えられる。

\section{6-2. 対象障害ごとの求められる建築構成}

次に建築構成について、知的型の施設は活動室面積について「不 足している」とする割合が多く (Fig. 22)、支援単位の規模が小さ い傾向にあり（Fig. 18）、今後の規模の意向について「減らしたい」 「バリエーションが欲しい」割合が多い（Fig. 24）。意向選択の理由 からは支援単位の規模を小さくすることが利用者の個別支援につな がることが示唆され（Table 5)、加えて生活単位の分割を実施する 割合が多い傾向があること（Fig. 21）から、知的型の施設では日中 活動空間・居住空間ともに個別支援がしやすい建築構成が求められ ていると考えられる。

次に身体型の施設では、活動室面積を「十分である」とする割 合が多く（Fig. 22）、生活単位の分割を実施しない割合も多い（Fig. 21）。支援単位の規模は大きい傾向があり（Fig. 18）、居室定員も多 い傾向にある（Fig. 19）が、施設建物の改善点として個室化に関す る要望が多く示されている (Table 6)。これらより、身体型の施設 においては個室化を進めつつも、生活単位の分割よりも緩やかな空

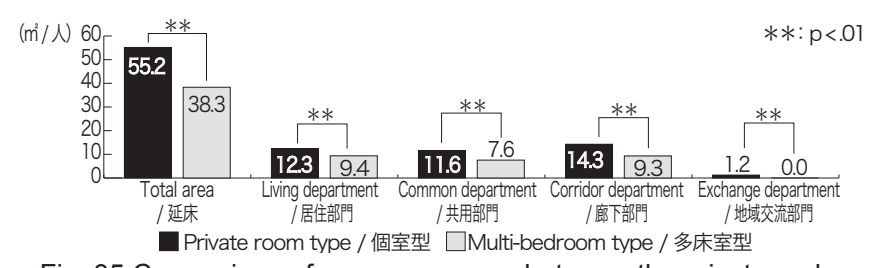

Fig. 35 Comparison of area per person between the private and multi-bedroom types by department / 個室型 · 多床室型の部門別 1 人あたり面積の比較

間の分節により見守り支援のしやすい建築構成が求められていると 言える。

具体的な居室・活動室面積について、居室面積は知的型よりも身 体型が大きい結果となった (Fig. 27)。この理由として、洗面・トイレ・ 天井走行リフト等の設備が設置されていることが予想されるが、本 調査の調査範囲外であり、今後更なる調査が求められる。活動室面 積については対象障害による有意差はみられない（Fig. 27）が、昼 夜分離を実施する施設にて大きい傾向が見られた（Fig. 29）。本調 查では、対象施設のほとんどが支援法施行以前に建設されており、 これら居室や活動室の面積傾向については、支援法以前の状況を反 映したものだと思われるが、少なくとも今後の施設計画において活 動室面積を考える際には、昼夜分離の実施の有無の検討が重要であ ると言える。

\section{6-3. 個室・生活単位の分割 · 㡺夜分離の状況と個室型・従来型} の面積比較

個室・生活単位の分割の状況について、全個室は全体の $24.4 \%$ （Fig. 10）で、生活単位の分割は全体の $16.9 \%$ で実施されている (Fig. 21) が、個室かつ小規模な生活単位を実践する個室ユニッ 卜型施設は少ない。個室化は対象障害によらず導入の要望が多く (Table 6)、今後の障害者支援施設の計画において特に重要な検討 点であると考えられる。昼夜分離は全体の $73.0 \%$ で実施され（Fig. 20)、具体的な建築構成としては「集約型」・分散型」が多い（Table 8）が、施設の立地状況が棟構成に影響している（Table 9）。

面積構成について、まず 1 人あたり部門面積の建築タイプ別の延 床面積の相関からは、個室ユニット型は廊下部門以外は高い相関が 見られず (Fig. 30)、施設の方針等により規模が異なることが示唆 された。個室型・多床室型で比較すると、部門別面積は多床室型は 管理・サービス等利用者が主に利用する以外のスペースの割合が小 さく（Fig. 34）、1 人あたり面積で見ると個室型は延床面積や居住・ 共用部門などが大きい（Fig. 35）。個室型施設は従来型施設に比べ、 利用者が利用する部分の面積が大きく、結果延床面積も大きい傾向 がある。また今回の調查では、個室型施設のうち、個室ユニット型 と個室従来型の面積構成に差はみられない結果となった。他方で、 個室ユニット型施設はその他施設に比べ支援単位の規模が小さく (Fig. 25)、職員数が多い（Fig. 25,26）傾向にあることが示され、生 活単位の小規模化には面積構成は影響せず、支援体制の充実の必要 があることが示唆された。

\section{6-4. まとめ}

本研究では、全国の障害者支援施設を対象にアンケート調査と平 面構成調査を行い、支援の実態や建築構成を明らかにすることを試 みた。結果、対象とする障害によって知的型・身体型・混合型に分 類されること、知的型では昼夜分離を基本とした個別的支援が目指 
される傾向があること、身体型では日中・夜間を通じた身体介助を 伴う支援が行われる傾向があること、昼夜分離を行う施設は活動室 面積が大きい傾向があること等を示した。また、障害者支援施設に おける生活の質の向上を図る上で建築計画上のポイントとなる個 室・生活単位の分割・昼夜分離については、その概況と実施にあたっ て考慮すべき点の整理を行い、個室であればユニット・従来型の間 で面積構成に違いが見られない事などを示した。今回示した障害者 支援施設の利用者像や支援の方針、面積的な状況については、支援 法以前からの状況の反映である可能性が高い。他方で今後新築され る障害者支援施設においては、支援法による障害種別の一元化や障 害者の住まいの地域移行の流れを受け、障害程度がより重度で、か つ多様な障害種別の利用者の入居が予想される。今後の課題として は、このような多様な障害を持ち、支援の傾向も異なる利用者の暮 ら寸障害者支援施設に対して、利用者の生活の質の向上と支援のし やすさの両者を担保する建築計画の検討と提案が挙げられる。

\section{謝辞}

本研究は、科学研究費・基盤研究 C (課題番号 19K04749) の助成 を受けたものである。また、本研究は日本建築学会学術講演会で発 表した研究 ${ }^{14,15)}$ に追加調查を行い、大幅に加筆・修正したもので ある。末筆になりましたが、本調查にご理解ご協力頂きました全国 の障害者支援施設の職員・利用者の皆様に、厚く御礼申し上げます。

注

注 1 )「障害者支援施設」とは、「障害者につき、施設入所支援を行うとともに、 施設入所支援以外の施設障害福祉サービスを行う施設」である。

注 2 ) 障害者自立支援法施行前後の障害福祉サービス体系の変化を以下に示す。

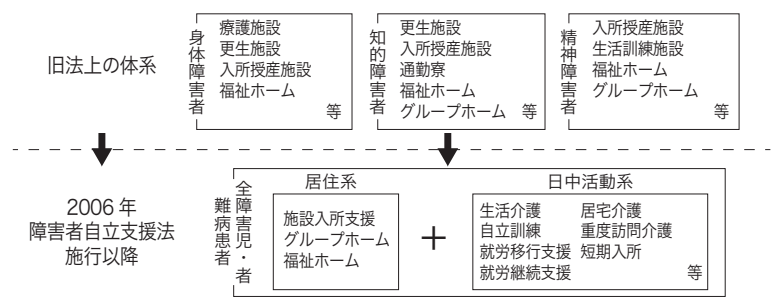

注 3 )「生活介護」とは、常に介護を必要とする人に、昼間、入浴、排泄、食 事の介護等を行うとともに、創作的活動又は生産活動の機会を提供するサー ビスである。施設によっては、絵画創作や書道、DVD 鑑賞、体操・ヨガ、簡 単な農作業、散歩、「スヌーズレン」を用いた活動、また強度行動障害のあ る方を対象とした簡単な「自立課題」を用いた活動などが行われている。

注 4$)$ 平成 30 年 10 月 1 日現在、障害者支援施設の施設数は 2544 施設、定員 数は 138,845 人である (厚生労働省平成 30 年社会福祉施設等調查より)。

注 5 ）障害者支援施設の対象者は、昼間実施サービスが生活介護の場合、障 害支援区分が区分 4（50 歳以上の場合区分 3 ）以上である者である。また、 障害者支援施設の設備・運営基準（厚生労働省令第 177 号障害者の日常生活 及び社会生活を総合的に支援するための法律に基づく障害者支援施設の設備 及び運営に関する基準より）のうち建築構成に関する項目を以下に示す。

施設規模

施設入所支援 30 人以上 ( 入所を目的とする他の社会福祉施設等に併設する場合 10 人以上) 昼間実施サービス 20 人以上 (入所を目的とする他の社会福祉施設等に併設する場合 10 人以上)

\begin{tabular}{|ll|}
\hline \multicolumn{1}{|c|}{ 設備基準 } \\
\hline 居室 & 定員4人以下、1 人似り面積 $9.9 \mathrm{~m}^{2}$ 以上（収納設備を除く） \\
訓練・作業室 & 支障がない広さ、必要な機械器具を備える \\
食堂 & 支障がない広さ、必要な部品を備える \\
浴室 & 利用者の特性に応じたものとする \\
便所 & 居室のある階ごとに設ける、利用者の特性に応じたものとする \\
洗面所 & 居室のある階ごとに設ける、利用者の特性に応じたものとする \\
廊下幅 & $1.5 \mathrm{~m}$ 以上（中廊下の場合 $1.8 \mathrm{~m}$ 以上) \\
\hline
\end{tabular}

注 6 ) WAMNET とは、独立行政法人福祉医療機構が運営する、福祉・保健・医療 の情報を総合的に提供している情報サイトである（https://www. wam. go.jp/ content/wamnet/pcpub/top/)。

注 7 ）文献 5 の分類を参考とし、居室と活動室の位置関係について、居住棟が 1 棟か複数棟か、またそれらが集約しているのか、分棟か、混在しているの かで分類を行った。なお、居住・活動以外（管理・サービス等）の室の位置 関係については考慮せず分類を行った。

注 8 ）文献 13 の分類を参考に、利用者が滞在する部分（居住部門・活動部門・ 共用部門)、職員が利用する部分（管理部門）、外部の方が出入りする可能性 が高い部分（サービス部門・医療部門・地域交流部門）、その他の部分（廊 下部門・収納部門）に分類した。ユニット型施設と従来型施設の分類基準を 統一するため、居住部門は居室のみとし、共用部は全て共用部門に含めた。

注 9 ) 分類した対象障害ごとの旧法上の施設種別について、各施設のホーム ページやWAMNETを用いた確認結果を下記に示す。WEB 上に記載がない施設や、 新体系に移行後に障害者支援施設として開設された施設については不明であ るが、確認することが出来た施設では「知的型」に旧法上の身体障害系施設 は含まれず、同様に「身体型」に旧法上の知的障害系施設は含まれないこと から、本分類を採用した。

\begin{tabular}{|ccccc|}
\hline & 旧法上の知的系施設 & 旧法上の身体系施設 & その他・不明 & 合計 \\
\hline 知的型 & 442 & 0 & 202 & 644 \\
身体型 & 0 & 134 & 39 & 173 \\
混合型 & 112 & 121 & 85 & 318 \\
\hline
\end{tabular}

注 10）DID 地区（人口集中地区）は、日本の国勢調査において設けられる、統 計データに基づき一定の基準により都市的地域を定めたものであり、原則と して人口密度が 1 平方キロメートル当たり 4,000 人以上の基本単位区等が市 区町村の境域内で瓦いに隣接し、それらの隣接した地域の人口が国勢調査時 に 5,000 人以上を有する地域と定義される。本研究では、各施設の住所デー 夕を用い、A ArcGIS により DID 内外を判定した。

注 11）職員が支援を行うために作るグループを指し、施設により空間条件を含 む場合と含まない場合がある。

注 12）文献 6 の定義を参考とした。

注 13）施設全体で生活単位の区別を実施する施設に加え、一部で生活単位の区 別を実施する施設を含む。

注 14）文献 16 より、一般的には 65 歳以上が高齢期であるが、知的障害者は高 齢年限が早く概ね 50 歳以上を高齢期と考えるべきだとされる。また、文献 17 では知的障害者関係の障害者支援施設では 50 代で老化・早期退行が問題 となる割合が 3 割を超える一方、身体障害者関係では 60 歳以上の層で 3 割 を超えることが示されている。

注 15）利用者 1 人あたり面積の母数は、施設内で主に生活する方々である「施 設入所支援と短期入所の利用定員の合計」とする。

注 16）障害者支援施設では制度上ユニットケアが定義されておらず、本調査で も生活単位の分割の定義として生活単位の定員を規定していないため、アン ケート調査で生活単位の分割を実施していると回答した施設には生活単位の 定員が 20 人以上の施設等も含まれる。他方で、高齢者施設や障害者グルー プホームにおけるユニット定員の基準が 10 人以下であることから、特に生 活単位の定員が 10 人以下である施設を「個室ユニット型施設」とし、生活 環境・職員配置に着目した分析を行った。

注 17）各施設のホームページ等を用いた確認を行った結果敷地内の一部の図面 が不足している等の理由から、調査項目によりサンプル数が異なる。部門面 積構成について、提供いただいた図面のうち個室小規模ユニット型に該当す る全 12 施設を対象とし、個室従来型・多床室型については対象障害・定員 規模・個室率により、各 12 施設をサンプリングした。個室率＝個室数／全 部屋数× 100 として算出し、多床室型は個室率 $20 \%$ 以下の施設とした。

注 18）経過措置とは、障害者自立支援法の施行日に現に存する旧法上の施設が 施設障害福祉サービスを提供する場合におううるこれらの建物について設け られる特例措置である。以下に居室面積に関する経過措置を示す。

\begin{tabular}{|c|c|c|c|}
\hline \multicolumn{4}{|c|}{ 収納設備等を除いた利用者 1 人あたりの床面積 } \\
\hline \multirow{2}{*}{ 現行基準 } & \multicolumn{3}{|c|}{ 経過措置 } \\
\hline & 旧身体障害者寮護施設 & 旧身体又は知的障害者更生施設·授産施設等 & 旧精神障害者生活訓楝施設·授産施設 \\
\hline $9.9 \mathrm{~m}^{2}$ 以上 & $6.6 \mathrm{~m}^{2}$ 以上 & $\begin{array}{l}\text { 6.6m²以上（旧法上の基準における規定 } \\
\text { を受けている施設に限り } 3.3 m^{2} \text { 以上) }\end{array}$ & 4.4m² \\
\hline
\end{tabular}

注 19）従来型とは、生活単位の区別を実施していない施設を示す。 


\section{参考文献}

1) Mitsubishi UFJ Research and Consulting : Survey on the actual conditions of support facilities for persons with disabilities (Ministry of Health, Labor and Welfare, 2018 Project for the Promotion of Comprehensive Welfare for Persons with Disabilities), <https://www.mhlw.go.jp/content/12200000/000521913. pdf $>, 2019.3$ (accessed 2019.8.19)

三菱U F J リサーチ\&コンサルティング : 障害者支援施設のあり方に関する 実態調査（平成 30 年度厚生労働省障害者総合福祉推進事業）,2019.3（参照 2019. 8. 19)

2 ) Japanese Association on Intellectual Disability : Report on the 2018 National Survey of Facilities and Businesses for Children and Persons with Intellectual Disabilities, <http://www.aigo.or.jp/choken/pdf/30chosa11ab.pdf>, 2019.3 (accessed 2020.8.3)

日本知的障害者福祉協会 : 平成 30 年度全国知的障害児 - 者施設 - 事業 実態 調査報告, 2019.3（参照 2020.8.3）

3 ) Yamada, A. and Koga, M. : Evaluation to the environment of facilities for the disabled by staff and problems for the cohabitatiom of the people having different kinds of disabilities. Study for the construction of living environment regardless of the kind of disabilities (1) , Journal of Architecture and Planning (Transactions of AIJ), Vol.76, No.664, pp.1083-1092, 2011.6 (in Japanese)

山田あすか、古賀政好 : 障碍者施設におけるスタッフによる環境への評価と 異種障碍者共同生活に向けての課題 障碍の別によらない生活環境構築のた めの研究その 1 , 日本建築学会計画系論文集, Vol.76, No.664, pp. 10831092, 2011.6

4) Ishii, S. : Research on the actual condition of living environment of unyt-type residential facilities for the elderly from layout plan view analysis, Journal of Architecture and Planning (Transactions of AIJ), Vol.75, No.656, pp.2307-2314, 2010.10 (in Japanese)

石井敏 : 平面図分析にもとづくユニット型高齢者介護施設の平面計画の実 態と考察, 日本建築学会計画系論文集, Vol.75, No.656, pp. 2307-2314, 2010. 10

5 ) Ishigaki, A. and Ikuta, K. : A study on the condition of downsizing the living unit in chidren's home, Journal of Architecture and Planning (Transactions of AIJ), Vol.77, No.671, pp.19-25, 2012.1 (in Japanese)

石垣文、生田京子：児童養護施設における生活単位小規模化の実態に関する 研究，日本建築学会計画系論文集，Vol.77，No.671，pp. 19-25，2012.1

6 ) Mitsubishi UFJ Research and Consulting :Survey and research to improve the quality of welfare services for persons with disabilities (Ministry of Health, Labor and Welfare, 2009 project to promote insurance welfare for persons with disabilities), <https://www.mhlw.go.jp/bunya/shougaihoken/cyousajigyou/ jiritsushien_project/seika/research_09/dl/result/02-05a.pdf> , 2010.3 (accessed 2020.8.3)

三菱U F J リサーチ\&コンサルティング : 障害福祉サービスの質の向上を 目指寸ための調査研究 (平成 21 年度厚生労働省障害者保険福祉推進事業), 2010.3 (参照 2020.8.3)

7 ) Matsumura, M., Takashima, T., Kawabata, M., and Sakurai, Y. : The hypothesis and it's verification on sheltered accommodation for people with severe physical and intellevtual disabilities, AIJ Journal of Technology and Design, No.22, pp.403-408, 2005.12 (in Japanese)

松村正希、高嶋友子、川畑美智子、桜井康宏 : グループホーム型障害者生活 施設の仮説と検証：身体障害者療護施設 D の実践報告, 日本建築学会技術 報告集，No. 22, pp. 403-408, 2005. 12

8 ) Miyazaki, T., He, X., and Miura, K. : Study on effects of change in Downsizing care with private room and eating place on the facility for people with mental disabilities, Proceeding of the architectural research meetings, Kinki Chapter, Architectural Institute of Japan, Architectural Planning and Design, No.52, pp.225-228, 2012.5 (in Japanese)

宮崎崇文、賀馨、三浦研 : 個室ユニット化・食事場所の変更が知的障害者の 滞在場所・行為に及ぼす影響に関する研究：障害者支援施設を対象として, 日本建築学会近畿支部研究報告集, 建築計画, No. 52, pp. 225-228, 2012.5

9 ) Matsuoka, S. and Akagawa, T. : Research on the relationship between unit care and the planning of facilities for the handicapped in Kyusyu, Proceeding of the architectural research meetings, Kyusyu Chapter, Architectural Institute of Japan, No.53, pp.77-80, 2014.3 (in Japanese)

松岡志延、赤川貴雄 : 身体障害者支援施設におけるユニット介護の導入状況 と平面構成に関する研究 : 九州地区における実態調查, 日本建築学会研究報
告, 九州支部, 計画系, No. 53, pp. 77-80, 2014.3

10) Kameya, E., Kanno, M., Yamamoto, K., Onoda, Y., and Sakaguchi, T. : A case study on environment for convalescence for the inpatient of ALS in welfarehome, Journal of Architecture and Planning (Transactions of AIJ), Vol.74, No.636, pp.339-345, 2009.2 (in Japanese)

亀屋惠三子、菅野實、山本和恵、小野田泰明、坂口大洋 : 身体障害者療護施 設におけるALS 罹病者の療養環境に関する事例的研究, 日本建築学会計画系 論文集，Vol.74，No.636，pp. 339-345，2009.2

11) Suzuki, M., Matsubara, A., and Kita, M. : Daily activities in facilities for intellectual disavilities and developmental disorders from the view of the individual are and the care, Proceeding of the architectural research meetings, Kinki Chapter, Architectural Institute of Japan, Architectural Planning and Design, No.56, 77-80, 2016.6 (in Japanese)

鈴木愛未、松原茂樹、木多道宏 : 障害者の個別エリアとスタッフの支援から みる日中活動の場の整備に関する研究一伊丹市Y施設を事例として一, 日本 建築学会近畿支部研究報告集, 計画系, No. 56, pp. 77-80, 2016.6

12) Sato, H., Matsui, H., Masaoka, T., and Suzuki, H. : A Research on Planning of the Industrial Trainning Institute for the Severely Physically Handicapped (Part 2) - Departmental Construction -, Summaries of Technical Papers of Annual Meeting, Architectural Institute of Japan, Architectural Planning and Design,Vol.59, pp.1215-1216, 1984.7 (in Japanese)

佐藤平、松井寿則、政岡知孝、鈴木弘之 : 重度身体障害者収容授産施設の建 築計画に関する研究 (その 2) : 部門構成について, 日本建築学会大会学術 講演梗概集, 計画系, No. 59, pp. 1215-1216, 1984.7

13) Sato, H., Matsui, H., Masaoka, T., and Suzuki, H. : A Research on Planning of the Industrial Trainning Institute for the Severely Physically Handicapped (Part 3) - Building Area -, Summaries of Technical Papers of Annual Meeting, Architectural Institute of Japan, Architectural Planning and Design,Vol.59, pp.1217-1218, 1984.7 (in Japanese)

佐藤平、松井寿則、政岡知孝、鈴木弘之 : 重度身体障害者収容授産施設の建 築計画に関する研究 (その 3 ) : 建築面積について, 日本建築学会大会学術 講演梗概集, 計画系, Vol. 59, pp. 1217-1218, 1984.7

14) Matsuda, Y. and Arakawa, M. : A nationwide survey on living environment of users in support facilities for persons with disabilities part 1: Operational status and users' situation, Summaries of Technical Papers of Annual Meeting, Architectural Institute of Japan, Architectural Planning and Design, pp.705706, 2020.7 (in Japanese)

松田雄二・荒川実緒子 : 障害者支援施設における利用者の生活環境に関する 全国調査その 1 全国の障害者支援施設の運営状況と利用者の実態につい て, 日本建築学会大会学術講演梗概集, 建築計画, pp. 705-706, 2020.7

15) Arakawa, M. and Matsuda, Y. : A nationwide survey on living environment of users in support facilities for persons with disabilities part 2: Facility planning and staff intentions for the care, Summaries of Technical Papers of Annual Meeting, Architectural Institute of Japan, Architectural Planning and Design, pp.707-708, 2020.7 (in Japanese)

荒川実緒子・松田雄二 : 障害者支援施設における利用者の生活環境に関する 全国調査その 2 全国の障害者支援施設の施設計画の状況について, 日本建 築学会大会学術講演梗概集, 建築計画, pp. 707-708, 2020.7

16) Nozomi-no-en, National Center for Presonants with Severe Intellectual Disabilities : Toward a Standard of Support for the Elderly and Mentally Retarded, <https://mhlw-grants.niph.go.jp/niph/search/NIDD00. do?resrchNum=201419004B>, 2015.10 (accessed 2020.5.5)

国立重度知的障害者総合施設のぞみの園 : 高齝知的障害者支援のスタンダー ドを目指して,2015.10（参照 2020.5.5）

17) Japanese Association on Intellectual Disability : Surveys and research on the nature of residential support for elderly persons with disabilities in the community (Ministry of Health, Labor and Welfare, 2012 Project for the Promotion of Comprehensive Welfare for Persons with Disabilities), <https:// www.mhlw.go.jp/seisakunitsuite/bunya/hukushi_kaigo/shougaishahukushi/ cyousajigyou/sougoufukushi/dl/h24_seikabutsu-29a.pdf>, 2013.3 (accessed 2020.5.8)

日本知的障害者福祉協会：地域における高齢の障害者の居住支援等の在 り方に関する調査. 研究 (厚生労働省平成 24 年度障害者総合福祉推進事 業）,2013.3（参照 2020.5.8） 


\title{
ACTUAL CONDITIONS OF SUPPORT AND ARCHITECTURAL CONFIGURATION OF FACILITIES FOR PERSONS WITH DISABILITIES
}

Focusing on target disabilities and private rooms, unit care, day/night separation, etc.

\author{
Mioko ARAKAWA ${ }^{* 1}$ and Yuji MATSUDA ${ }^{* 2}$
}

${ }^{11}$ Former Grad. Student, Dept. of Arch., Grad. School of Eng., The Univ. of Tokyo
${ }^{2}$ Assoc. Prof., Dept. of Arch., Grad. School of Eng., The Univ. of Tokyo, Dr.Eng.

In this study, a questionnaire survey of support facilities for persons with disabilities throughout Japan and a floor plan analysis on some of those facilities were conducted. From these surveys, we analyzed the relationship between the characteristics of the disabilities of residents and the care and building conditions, as well as the implementation status of private rooms, unit care, and day/night separation. The results are as follows.

1) Facilities mainly for people with intellectual disabilities tend to be regarded as "residences for people who need a structured environment, mainly for people with severe behavioral disorders," and they tend to adopt a policy of having everyone participate in daytime activity programs, with $74.1 \%$ implementing day/night separation. In addition, in residential settings, there is a tendency to have smaller support units and a higher percentage of implementation of the division of living units. In terms of the staff's intentions regarding future improvements in facilities and care, the following were pointed out: expansion of the activity room area, reduction of the size of the support unit, and barrier-free access.

2) Facilities mainly for people with physical disabilities tend to be regarded as "residences for people with the most severe disabilities who require extensive support with physical assistance" or "residences for people who require medical care." In addition, many of these facilities tend to have a policy of allowing free participation in daytime activity programs or not having any programs, and do not implement day/night separation. In residential settings, there is a tendency to have larger support units and room capacities, and a higher percentage not to implementing the division of living units. In terms of the staff's intentions regarding future improvements in facilities and care, there were requests for support such as the introduction of nursing care equipment.

3) In terms of the specific building configuration of day/night separation, the most common types are the "centralized type" in which rooms and activity rooms are contained in one building and separated by area or floor, and the "decentralized type" in which the building is divided into several buildings with different functions such as residence and activity.

4) Compared to the "multi-bedroom type" facilities, the proportion of area occupied by management and services is smaller than in "private room type" facilities, and the area of bedrooms, common areas, and total floor space per person tend to be larger. Among the "private room type" facilities, there is no difference in the area composition between the "unit-type" and "conventionaltype" facilities. "unit-type" facilities tend to have more staff than the other facilities.

These results suggest that facilities mainly for the people with intellectual disabilities tend to be conscious of creating a clear rhythm of life through the activity programs and architectural configuration of the facilities, and that architectural configurations that facilitate the creation of structured environment and individual support are required. On the other hand, in the case of facilities mainly for the people with physical disabilities, the creation of a clear rhythm of life is not so important, and it is suggested that the ease of providing both direct support, such as physical assistance, and indirect support, such as watching over, is required. In addition, when implementing unit care, it is necessary to consider the support system rather than the architectural configuration. 